\title{
Carbon dioxide emissions from the flat bottom and shallow Nam Theun 2 Reservoir: drawdown area as a neglected pathway to the atmosphere
}

\author{
Chandrashekhar Deshmukh ${ }^{1,2,3, a}$, Frédéric Guérin ${ }^{1,4,5}$, Axay Vongkhamsao ${ }^{6}$, Sylvie Pighini $^{6, b, c}$, Phetdala Oudone $^{6, d}$, \\ Saysoulinthone Sopraseuth ${ }^{6}$, Arnaud Godon ${ }^{6, e}$, Wanidaporn Rode $^{6}$, Pierre Guédant ${ }^{6}$, Priscia Oliva ${ }^{1}$, \\ Stéphane Audry ${ }^{1}$, Cyril Zouiten ${ }^{1}$, Corinne Galy-Lacaux ${ }^{2}$, Henri Robain ${ }^{7}$, Olivier Ribolzi ${ }^{1}$, Arun Kansal ${ }^{3}$, \\ Vincent Chanudet ${ }^{8}$, Stéphane Descloux ${ }^{8}$, and Dominique Serça ${ }^{2}$ \\ ${ }^{1}$ Géosciences Environnement Toulouse (GET), Université de Toulouse (UPS), 14 Avenue E. Belin, 31400 Toulouse, France \\ ${ }^{2}$ Laboratoire d'Aérologie, Université de Toulouse, CNRS UMR 5560, 14 Av. Edouard Belin, 31400, Toulouse, France \\ ${ }^{3}$ Centre for Regulatory and Policy Research, TERI University, New Delhi, India \\ ${ }^{4}$ IRD, UR 234, GET, 14 Avenue E. Belin, 31400, Toulouse, France \\ ${ }^{5}$ Departamento de Geoquimica, Universidade Federal Fluminense, Niterói, Brasil \\ ${ }^{6}$ Nam Theun 2 Power Company Limited (NTPC), Environment \& Social Division, Water Quality and Biodiversity Dept., \\ Gnommalath Office, P.O. Box 5862, Vientiane, Lao PDR \\ ${ }^{7}$ IRD, iEES-Paris, Centre IRD France-Nord, 32 avenue Henri Varagnat, 93143 Bondy CEDEX, France \\ ${ }^{8}$ Electriciteì de France, Hydro Engineering Centre, Sustainable Development Dpt., Savoie Technolac, \\ 73373 Le Bourget du Lac, France \\ ${ }^{a}$ now at: Asia Pacific Resources International Limited (APRIL), Indonesia \\ ${ }^{b}$ now at: Innsbruck University, Institute of Ecology, 15 Sternwartestrasse, 6020 Innsbruck, Austria \\ ${ }^{\mathrm{c}}$ now at: Foundation Edmund Mach, FOXLAB-FEM, Via E. Mach 1, 38010 San Michele all' Adige, Italy \\ ${ }^{d}$ now at: Department of Environmental Science, Faculty of Environmental Sciences, \\ National University of Laos, Vientiane, Lao PDR \\ enow at: Arnaud Godon Company, 44 Route de Genas, Nomade Lyon, 69003 Lyon, France
}

Correspondence: Frédéric Guérin (frederic.guerin@ird.fr)

Received: 4 September 2017 - Discussion started: 22 September 2017

Revised: 30 January 2018 - Accepted: 9 February 2018 - Published: 26 March 2018

\begin{abstract}
Freshwater reservoirs are a significant source of $\mathrm{CO}_{2}$ to the atmosphere. $\mathrm{CO}_{2}$ is known to be emitted at the reservoir surface by diffusion at the air-water interface and downstream of dams or powerhouses by degassing and along the river course. In this study, we quantified total $\mathrm{CO}_{2}$ emissions from the Nam Theun 2 Reservoir (Lao PDR) in the Mekong River watershed. The study started in May 2009, less than a year after flooding and just a few months after the maximum level was first reached and lasted until the end of 2013. We tested the hypothesis that soils from the drawdown area would be a significant contributor to the total $\mathrm{CO}_{2}$ emissions.

Total inorganic carbon, dissolved and particulate organic carbon and $\mathrm{CO}_{2}$ concentrations were measured in 4 pristine
\end{abstract}

rivers of the Nam Theun watershed, at 9 stations in the reservoir (vertical profiles) and at 16 stations downstream of the monomictic reservoir on a weekly to monthly basis. $\mathrm{CO}_{2}$ bubbling was estimated during five field campaigns between 2009 and 2011 and on a weekly monitoring, covering water depths ranging from 0.4 to $16 \mathrm{~m}$ and various types of flooded ecosystems in 2012 and 2013. Three field campaigns in 2010, 2011 and 2013 were dedicated to the soils description in 21 plots and the quantification of soil $\mathrm{CO}_{2}$ emissions from the drawdown area. On this basis, we calculated total $\mathrm{CO}_{2}$ emissions from the reservoir and carbon inputs from the tributaries. We confirm the importance of the flooded stock of organic matter as a source of carbon (C) fuelling emissions. We show that the drawdown area contributes, depending on 
the year, from 40 to $75 \%$ of total annual gross emissions in this flat and shallow reservoir. Since the $\mathrm{CO}_{2}$ emissions from the drawdown zone are almost constant throughout the years, the large interannual variations result from the significant decrease in diffusive fluxes and downstream emissions between 2010 and 2013. This overlooked pathway in terms of gross emissions would require an in-depth evaluation for the soil organic matter and vegetation dynamics to evaluate the actual contribution of this area in terms of net modification of gas exchange in the footprint of the reservoir, and how it could evolve in the future.

\section{Introduction}

Carbon dioxide $\left(\mathrm{CO}_{2}\right)$ emissions from inland waters were recently revisited and it appears that emissions from freshwater reservoirs contribute significantly despite the disproportionally small surface area of these systems (Barros et al., 2011; Raymond et al., 2013; Deemer et al., 2016). The $\mathrm{CO}_{2}$ production and subsequent emissions in reservoirs result from the degradation of the flooded organic matter $(\mathrm{OM})$ and the OM originating from the watershed (Galy-Lacaux et al., 1997b; Abril et al., 2005; Guérin et al., 2008; Barros et al., 2011; Teodoru et al., 2011). As the amount of labile OM originating from the flooded soils and biomass decreases with time due to the progressive mineralization of the carbon stock, emissions decrease progressively with reservoir ageing (Abril et al., 2005; Barros et al., 2011). $\mathrm{CO}_{2}$ emissions are higher in tropical reservoirs than in temperate and boreal ones, a latitudinal difference attributed to the enhancement of OM degradation with temperature (Barros et al., 2011; Marotta et al., 2014; Yvon-Durocher et al., 2014). Emissions occur through diffusion at the air-water interface of the reservoir and from rivers downstream of dams (Abril et al., 2005; Guérin et al., 2006; Kemenes et al., 2011). At the surface of reservoirs, it is well known that emissions significantly vary spatially and temporally. Spatial variations can be higher than temporal variations (Roland et al., 2010; Teodoru et al., 2011; Zhao et al., 2013; Pacheco et al., 2015). Thus, the integration of both temporal and spatial variations is mandatory for the determination of accurate emission factors.

In some reservoirs with large water-level variations, large surface areas of soils known as drawdown zones are periodically exposed to the atmosphere (for example, the Three Gorges and Nam Theun 2 reservoirs). Recently, the importance of the drawdown emissions was pointed out as a significant source of $\mathrm{CH}_{4}$ in the Three Gorges Dam in China (Chen et al., 2009, 2011; Yang et al., 2012) and a very minor source at Nam Theun 2 Reservoir (NT2R; Serça et al., 2016). $\mathrm{CO}_{2}$ emission from the drawdown area was only measured in agricultural plots of the drawdown area of the Three Gorges Dam (Li et al., 2016). However, the hypothesis of significant $\mathrm{CO}_{2}$ emissions from those soils seasonally flooded and exposed to air was never tested in unmanaged drawdown areas representative of tropical reservoirs with large water-level variations. In the present study, we measured $\mathrm{CO}_{2}$, organic and inorganic carbon concentrations and physico-chemical parameters at 9 stations in the NT2R and 16 stations downstream of the dam and the powerhouse. This weekly to fortnightly sampling was conducted in order to estimate emissions from the reservoir surface and downstream emissions during 4.5 years of monitoring after impoundment. We also measured $\mathrm{CO}_{2}$ emissions from the large drawdown area of the NT2R that represented seasonally up to $65 \%$ of the maximum reservoir area during the study. The spatial, seasonal and interannual variation in emissions by all of the above-listed pathways and their contribution to total gross $\mathrm{CO}_{2}$ emissions will be discussed.

\section{Material and methods}

\subsection{Study site}

The NT2R is located in the Lao People's Democratic Republic (Lao PDR), it was impounded in April 2008 and was commissioned in April 2010. It floods $489 \mathrm{~km}^{2}$ of very diverse types of ecosystems including forest, agricultural soils and wetlands (Descloux et al., 2011). Geological formations responsible for the soil development in the NT2R area are mainly composed of more or less consolidated sedimentary rocks (Lovatt Smith et al., 1996; Smith and Stokes, 1997). The parental rocks belong to the Khorat group and Phon Hong group formations (Cretaceous) with two main lithologies: (1) late cretaceous Maha Sarakham formation (i.e. evaporites and mudstones) and (2) aptian Khot Kruat formation (i.e. mainly fluvial formation of red siltstones and sandstones)

The NT2R, described in detail in Descloux et al. (2016); Deshmukh et al. (2016) and Guérin et al. (2016) is under the influence of a monsoon subtropical climate with three main seasons: the cold dry season $(\mathrm{CD}$, from mid-October to mid-February), the warm dry season (WD, from midFebruary to mid-June) and the warm wet season (WW, from mid-June to mid-October). Owing to the large seasonal variations in the river discharges in the region, the reservoir area ranged seasonally between $489 \mathrm{~km}^{2}$ in the WW season and $170 \mathrm{~km}^{2}$ in the WD season during the course of the study. Conversely, the surface of the drawdown area reached its maximum $\left(320 \mathrm{~km}^{2}\right)$ when the water level was the lowest. During the monitoring, the wettest years were 2011 and 2013 with an average water discharge in the reservoir of $\sim 270 \mathrm{~m}^{3} \mathrm{~s}^{-1}$, whereas the driest year was 2012 with a discharge of $230 \mathrm{~m}^{3} \mathrm{~s}^{-1}$. In 2011, the reservoir had the largest water-level variation with the largest surface area of the monitoring in the wet season $\left(491 \mathrm{~km}^{2}\right)$ and the smallest of the monitoring in the WD season $\left(168 \mathrm{~km}^{2}\right)$. The NT2R is a trans-basin reservoir with two downstream sections: one be- 


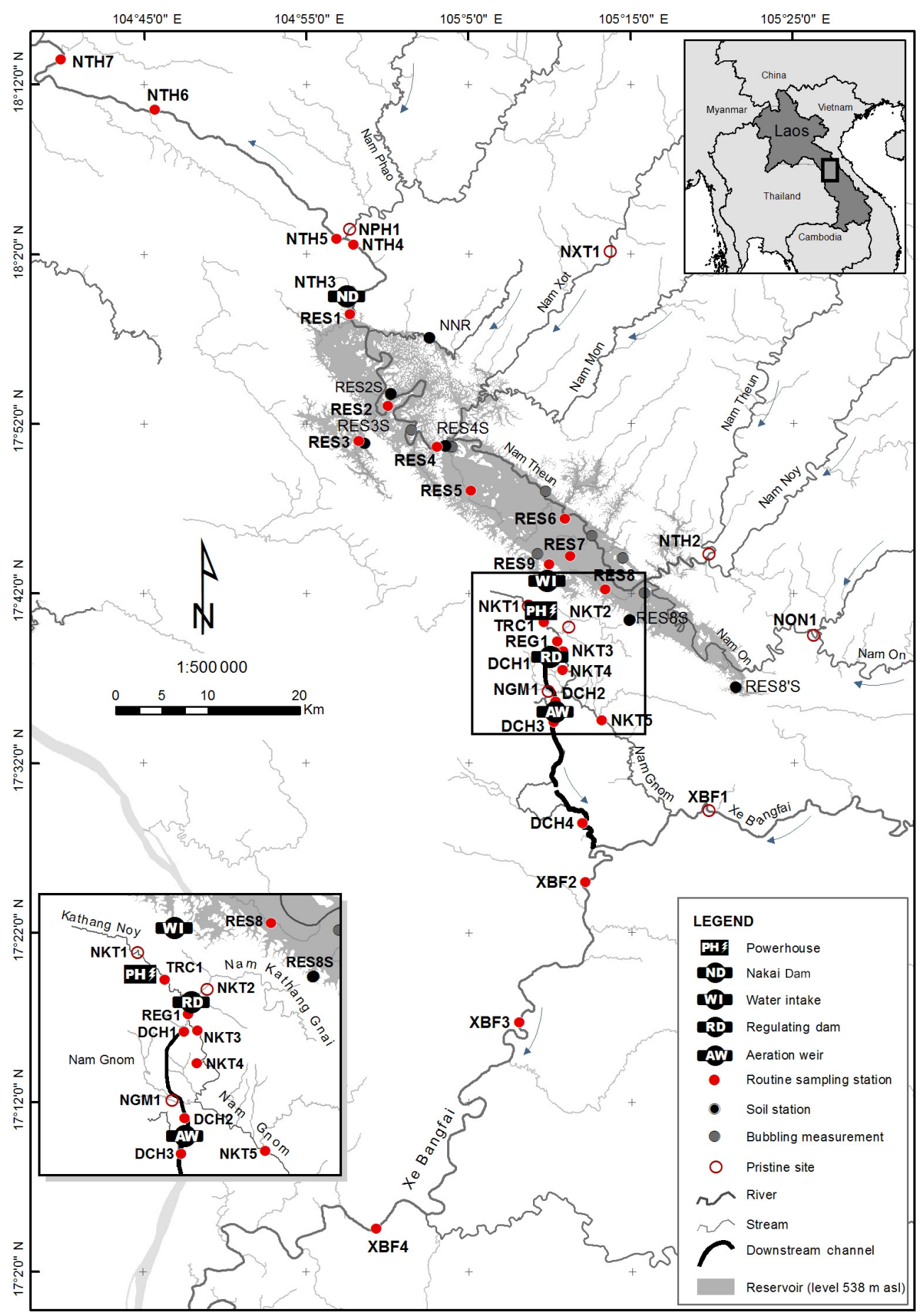

Figure 1. Map of the Nam Theun 2 monitoring network. The station names are defined by numbers and an abbreviated name as follow: RES standing for reservoir, NTH for Nam Theun River, NON for Nam On River, NXT for Nam Xot, NPH1 for Nam Phao River, TRC for tail race channel, REG for regulation pond, DCH for downstream channel, NKT for Nam Kathang River, NGM for Nam Gnom and XBF for Xe Bangfai River.

low the powerhouse and one below the Nakai Dam (Fig. 1). Except for during the occasional use of the spillways, only $2 \mathrm{~m}^{3} \mathrm{~s}^{-1}$ of water are discharged downstream of the Nakai Dam in the Nam Theun River and around $240 \mathrm{~m}^{3} \mathrm{~s}^{-1}$ are re- leased to the powerhouse, the regulating pond and finally the artificial downstream channel before water reaches the $\mathrm{Xe}$ Bangfai River (Fig. 1). 


\subsection{Sampling strategy}

The $\mathrm{CO}_{2}$ and $\mathrm{O}_{2}$ concentrations in water and the water temperature were determined in surface waters of six pristine rivers and three rivers under the influence of the reservoir (10 stations) and in the artificial channel (5 stations), whereas it was done along vertical profiles in the reservoir (9 stations) and the regulation pond (1 station; Fig. 1). At all sites located downstream of the powerhouse, sampling was done weekly (from March 2010 to December 2013), whereas it was done fortnightly in incoming pristine rivers and in the reservoir (from May 2009 to December 2013). The stations RES1RES3 flooded dense forest, the stations RES4-RES6 flooded degraded forest, the station RES7 flood swamps and the station RES8 flooded a rice field area (Descloux et al., 2011; Guérin et al., 2016). The station RES9 is located at the water intake, an area of continuous vertical mixing of the water column, where $\mathrm{CH}_{4}$ emissions are enhanced (Guérin et al., 2016). Degassing of $\mathrm{CO}_{2}$ was calculated below the Nakai Dam, just below the turbines at TRC1, below the regulating dam (RD in Fig. 1) and at the aeration weir (AW in Fig. 1). Bubbling of $\mathrm{CO}_{2}$ was determined during five field campaigns covering different seasons and sites in 2009, 2010 and 2011, and during a weekly monitoring from March 2012 to August 2013 at seven stations. In the drawdown area, soil description was conducted in June 2010 at six sites and $\mathrm{CO}_{2}$ emissions were repeatedly measured at 21 plots over those sites in June 2010, 2011 and 2013.

\subsection{In situ measurements and water analysis}

Vertical profiles of $\mathrm{O}_{2}, \mathrm{pH}$ and temperature were measured in situ at all sampling stations with a multi-parameter probe Quanta $^{\circledR}$ (Hydrolab, Austin, Texas) since January 2009. In the reservoir, the vertical resolution was $0.5 \mathrm{~m}$ down to $5 \mathrm{~m}$ and $1 \mathrm{~m}$ deeper. Surface and deep-water samples for $\mathrm{CO}_{2}$, dissolved organic carbon (DOC), particulate organic carbon (POC) and dissolved inorganic carbon (DIC) concentrations were taken with a surface water sampler (Abril et al., 2007) and a UWITEC ${ }^{\mathrm{TM}}$ sampling bottle, respectively. Water samples for $\mathrm{CO}_{2}$ determination were stored in serum glass vials, capped with butyl stoppers, sealed with aluminium crimps and preserved (Guérin and Abril, 2007). $\mathrm{CO}_{2}$ concentrations were determined by the headspace technique and using the solubility coefficient of Weiss (1974) as in Guérin et al. (2006). The $\mathrm{CO}_{2}$ partial pressure in the headspace was determined by gas chromatography (GC; SRI 8610C gas chromatograph, Torrance, CA, USA) equipped with a flame ionization detector and a methanizer (Chanudet et al., 2011). Commercial gas standards (400, 1000 and 3000 ppmv, Air Liquid "crystal" standards) were injected after every 10 samples for calibration. The detection limit was $<1 \mathrm{ppmv}$ in the headspace and duplicate injection of samples showed reproducibility better than $5 \%$. For TIC, DOC and POC analyses were performed with a Shimadzu TOC- $\mathrm{V}_{\mathrm{CSH}}$ analyser. Fil- tered $(0.45 \mu \mathrm{m}$, Nylon) and unfiltered samples were analysed for TIC and total organic carbon (TOC). POC was calculated by the difference between TOC and DOC concentrations in unfiltered and filtered samples. The detection limit was $8 \mu \mathrm{mol} \mathrm{L}^{-1}$ and the uncertainty was $2.0 \mu \mathrm{mol} \mathrm{L}^{-1}$ in TOC and DOC and $2.8 \mu \mathrm{mol} \mathrm{L}^{-1}$ in POC.

\subsection{Organic and inorganic carbon inputs from the watershed to the reservoir}

Carbon inputs were calculated on a monthly basis using monthly averages of the river discharge of the four main tributaries of the NT2R. The Nam Theun River contributed $32 \%\left(27 \mathrm{~m}^{3} \mathrm{~s}^{-1}\right)$ of the total discharge, while Nam Xot $\left(22 \mathrm{~m}^{3} \mathrm{~s}^{-1}\right)$, Nam On $\left(19 \mathrm{~m}^{3} \mathrm{~s}^{-1}\right)$ and Nam Noy $\left(25 \mathrm{~m}^{3} \mathrm{~s}^{-1}\right.$; not monitored for biogeochemistry) contributed 23, 22 and $24 \%$, respectively. For the Nam On River, the specific water discharge and POC, DOC, TIC and $\mathrm{CO}_{2}$ from this river were used. For the other rivers, the specific water discharge of each river was used together with the average DOC, POC, TIC and $\mathrm{CO}_{2}$ from Nam Theun, Nam Phao and Nam Xot rivers all located in the Nam Theun watershed. Note that the Nam Phao reaches the Nam Theun River downstream of the Nakai Dam but we used this dataset together with the ones from other rivers to calculate the carbon inputs since the physicochemical parameters and carbon concentrations are not different from other rivers in the watershed.

\subsection{Diffusive fluxes and degassing}

Diffusive fluxes at the air-water interface of the reservoir were calculated from the surface $\mathrm{CO}_{2}$ concentrations, wind speed and rainfall rates using the gas transfer velocity formulations of Guérin et al. (2007) and MacIntyre et al. (2010) as already described for $\mathrm{CH}_{4}$ fluxes from this reservoir (Deshmukh et al., 2014; Guérin et al., 2016). Based on physical modelling and in situ measurements (Chanudet et al., 2012), we determined that the station RES9 located at the water intake is representative of an area of about $3 \mathrm{~km}^{2}$ (i.e. $0.6 \%$ of the reservoir water surface at full reservoir water level), whatever the season (Guérin et al., 2016). This area was therefore used to extrapolate specific diffusive fluxes from this station. For other stations, diffusive fluxes are calculated with the daily meteorological parameters and reservoir water surface area from the capacity curve. Degassing downstream of the powerhouse, the regulating dam and the aeration weir, all located along the artificial channel and downstream of the Nakai Dam (Fig. 1), were computed using the $\mathrm{CO}_{2}$ concentration upstream and downstream of these civil structures and the water discharge as in Deshmukh et al. (2016) for $\mathrm{CH}_{4}$. The diffusion from the rivers and artificial channel below the powerhouse and the dam was calculated using a constant gas transfer velocity of $10 \mathrm{~cm} \mathrm{~h}^{-1}$ (Deshmukh et al., 2016). 
Table 1. Soil type and characteristics at the sampling station of the drawdown area of the Nam Theun 2 Reservoir (Lao PDR). KKK formation.

\begin{tabular}{|c|c|c|c|c|c|c|c|c|}
\hline Catena & Solum & $\% \mathrm{~N}$ & $\% \mathrm{C}$ & $\mathrm{C}: \mathrm{N}$ & $\mathrm{pH}$ & Soil name WRB FAO & Soil texture & Lithology \\
\hline \multirow[t]{3}{*}{ NNR } & NNR upland & 0.11 & 1.47 & $13.69 \pm 1.73$ & 4.33 & \multirow{3}{*}{$\begin{array}{l}\text { planosol } \\
\text { endogleyic planosol } \\
\text { gleysol }\end{array}$} & \multirow[t]{3}{*}{ sandy } & \multirow{3}{*}{$\begin{array}{l}\text { micaceous } \\
\text { quartzose }\end{array}$} \\
\hline & NNR interm. down & 0.10 & 1.32 & $13.55 \pm 1.84$ & & & & \\
\hline & NNR shoreline & 0.13 & 1.89 & $14.78 \pm 1.60$ & 4.23 & & & \\
\hline \multirow[t]{3}{*}{ RES3S } & RES3 upland & 0.18 & 2.38 & $13.21 \pm 0.63$ & 4.18 & \multirow{3}{*}{$\begin{array}{l}\text { plinthosol } \\
\text { etagnic plinthosol } \\
\text { plinthic stagnosol }\end{array}$} & \multirow[t]{3}{*}{ clay } & \multirow{3}{*}{$\begin{array}{l}\text { red } \\
\text { mudstone }\end{array}$} \\
\hline & RES3 interm. & & & & & & & \\
\hline & RES3 shoreline & 0.17 & 1.95 & $11.21 \pm 0.56$ & 4.88 & & & \\
\hline \multirow[t]{3}{*}{ RES2S } & RES2 upland & 0.16 & 2.24 & $13.62 \pm 0.60$ & & \multirow{3}{*}{$\begin{array}{l}\text { plinthic ferralsol } \\
\text { "stagnic" ferralsol } \\
\text { stagnosol }\end{array}$} & \multirow[t]{3}{*}{ sandy clay } & \multirow{3}{*}{$\begin{array}{l}\text { micaceous } \\
\text { sandstone }\end{array}$} \\
\hline & RES2 interm. & 0.20 & 2.30 & $11.25 \pm 0.50$ & & & & \\
\hline & RES2 shoreline & 0.13 & 1.41 & $10.55 \pm 0.54$ & & & & \\
\hline \multirow[t]{4}{*}{ RES8S } & RES8 upland & 0.08 & 1.76 & $23.47 \pm 3.95$ & & \multirow{4}{*}{$\begin{array}{l}\text { acrisol } \\
\text { stagnic acrisol } \\
\text { stagnic acrisol } \\
\text { endogleyic stagnosol }\end{array}$} & \multirow[t]{4}{*}{ sandy clay } & \multirow{4}{*}{$\begin{array}{l}\text { quaternary } \\
\text { deposits }\end{array}$} \\
\hline & RES8 interm. up & 0.06 & 0.68 & $11.93 \pm 1.46$ & & & & \\
\hline & RES8 interm. down & 0.09 & 1.31 & $13.99 \pm 1.99$ & & & & \\
\hline & RES8 shoreline & 0.12 & 2.02 & $17.07 \pm 1.93$ & & & & \\
\hline \multirow[t]{2}{*}{ RES8'S } & RES8' upland & 0.05 & 0.77 & $16.15 \pm 2.30$ & & \multirow{2}{*}{$\begin{array}{l}\text { acrisol } \\
\text { endogleyic stagnosol }\end{array}$} & \multirow[t]{2}{*}{ sandy clay } & \multirow{2}{*}{$\begin{array}{l}\text { quaternary } \\
\text { deposits }\end{array}$} \\
\hline & RES8' shoreline & 0.08 & 1.51 & $18.22 \pm 2.79$ & & & & \\
\hline \multirow[t]{4}{*}{ RES4S } & RES4 upland & 0.16 & 1.98 & $12.76 \pm 1.17$ & 4.14 & \multirow{4}{*}{$\begin{array}{l}\text { acrisol } \\
\text { stagnic acrisol } \\
\text { stagnic acrisol } \\
\text { gleysol }\end{array}$} & \multirow[t]{4}{*}{ sandy clay } & \multirow{4}{*}{$\begin{array}{l}\text { micaceous } \\
\text { sandstone }\end{array}$} \\
\hline & RES4 interm. up & 0.13 & 1.92 & $14.66 \pm 1.58$ & & & & \\
\hline & RES4 interm. down & 0.12 & 1.67 & $14.33 \pm 1.71$ & & & & \\
\hline & RES4 shoreline & 0.10 & 1.36 & $14.35 \pm 1.97$ & 4.44 & & & \\
\hline
\end{tabular}

\section{$2.6 \mathrm{CO}_{2}$ bubbling}

Bubbling of $\mathrm{CO}_{2}$ was determined with funnels (Deshmukh et al., 2014) during five field campaigns covering different seasons (between May 2009 and June 2011), and during a weekly monitoring from March 2012 to August 2013. During this monitoring, spatial variation was explored through measurements spread over six stations (Fig. 1) representative of the different types of flooded ecosystems (dense and medium forests, light and degraded forest, and agricultural lands as determined by Descloux et al., 2011), and with different depths (from 0.4 to $16 \mathrm{~m}$ ) at each station. We stopped measuring bubbling at sites deeper than $16 \mathrm{~m}$ after no ebullition was observed during the first three campaigns. Bubble samples were taken with a $50 \mathrm{~mL}$ syringe and the syringe was immediately connected to a $\mathrm{N}_{2}$-preflushed $10 \mathrm{~mL}$ serum vial, leading to a dilution factor of 5/6 (Guérin et al., 2007). Gas samples were analysed with the GC described above.

\subsection{Soil descriptions and $\mathrm{CO}_{2}$ fluxes from the drawdown area}

Since the drawdown area of the NT2R could represent up to $65 \%$ of the surface area of the reservoir at the end of the WD season, emissions from this major area under the influence of flooding were evaluated. Soil types were determined together with $\mathrm{CO}_{2}$ emissions. Soil description was carried out in June 2010 at six sites and soils from the station RES4S plot were characterized in detail in June 2013
(Fig. 1, Table 1). Four sites were selected in the Nam Theun River riparian's area (NMR, RES2S, RES4S, RES8S'), one site in the flooded primary forest (RES3S) and one site in the flooded agricultural area (RES8S). Soil study was conducted through soil catenae of two to four soils profiles from the pristine soils on top ("upland" samples) to the shoreline of the reservoir ("shoreline" samples). One or two other soil profiles were performed in between ("interm. up" and "interm. down" samples, with "interm" standing for intermediate). Soil sampling was performed with an Edelman soil corer down to a depth of $1 \mathrm{~m}$, but only $0-20 \mathrm{~cm}$ depth samples were considered in this study. Information on horizon depth, soil texture and structure (e.g. compactness, porosity), colour (Munssel chart for soil colour), soil fauna activity, and pedological features (e.g. redoximorphic features, concretions) were provided through soil descriptions in the field. Samples for $\mathrm{C}, \mathrm{N}$ and $\mathrm{pH}$ were selected following the horizon apparition for each soil profile. They were manually decompacted and stored in plastic bags. Back in the laboratory, soil samples were dried out at room temperature under a laminar flow hood, sieved at $2 \mathrm{~mm}$ and properly split in two representative subsamples. One of the subsamples was crushed with an agate mortar before chemical analysis. The non-crushed subsample was dedicated to soil $\mathrm{pH}$ and granulometric measurements. $\mathrm{C}$ and $\mathrm{N}$ analysis where performed with a Elementar Vario EL III C / N / S analyser and soil pH measurements were performed in ultrapure water $(18.2 \mathrm{M} \Omega)$ following ISO 11464 standard procedure. 
Table 2. Temperature $\left({ }^{\circ} \mathrm{C}\right)$, relative humidity $(\%)$ and $\mathrm{CO}_{2}$ fluxes $\left(m m o l \mathrm{~m}^{-2} \mathrm{~d}^{-1}\right)$ from the soils of the drawdown area of the Nam Theun 2 Reservoir (Lao PDR).

\begin{tabular}{|c|c|c|c|c|c|c|c|c|c|}
\hline \multirow[b]{2}{*}{ Site } & \multicolumn{3}{|c|}{2010} & \multicolumn{3}{|c|}{2011} & \multicolumn{3}{|c|}{2013} \\
\hline & Hum. & Temp. & $\mathrm{CO}_{2}$ flux & Hum. & Temp. & $\mathrm{CO}_{2}$ flux & Hum. & Temp. & $\mathrm{CO}_{2}$ flux \\
\hline NNR upland & 17.5 & 25.7 & $265 \pm 37$ & 18.3 & 24.4 & $328 \pm 43$ & & & \\
\hline NNR interm. up & & & & 26.9 & 27.5 & $669 \pm 56$ & & & \\
\hline NNR interm. down & 19.6 & 32.3 & $201 \pm 19$ & 23.7 & 29 & $251 \pm 99$ & & & \\
\hline NNR shoreline & 37 & 31.9 & 40 & 46.4 & 27.3 & $67 \pm 7$ & & & \\
\hline RES3S upland & 22.3 & 26.8 & 231 & 23.6 & 25.6 & $366 \pm 14$ & & & \\
\hline RES3S interm. & 49.5 & 27.4 & $184 \pm 50$ & 30.2 & 26.1 & $186 \pm 57$ & & & \\
\hline RES3S shoreline & 42.3 & 28.3 & $503 \pm 97$ & 25.6 & 19.8 & $391 \pm 23$ & & & \\
\hline RES2S upland & 19.9 & 26.4 & $183 \pm 1$ & 24.5 & 25.2 & $531 \pm 41$ & & & \\
\hline RES2S interm. & 34.6 & 29.2 & $138 \pm 21$ & 30.2 & 26.1 & $339 \pm 52$ & & & \\
\hline RES2S shoreline & 49.4 & 28.5 & $332 \pm 5$ & 48.7 & 27.1 & $166 \pm 23$ & & & \\
\hline RES8S upland & 27.7 & 28.2 & $86 \pm 0$ & 26.9 & 27.0 & 468 & & & \\
\hline RES8S interm. up & 32.3 & 28.3 & $75 \pm 15$ & 33.2 & 26.9 & $300 \pm 19$ & & & \\
\hline RES8S interm. down & 32.9 & 29.1 & $110 \pm 10$ & 32.3 & 27.8 & $239 \pm 44$ & & & \\
\hline RES8S shoreline & 45.3 & 29.7 & $286 \pm 59$ & 44.5 & 28.5 & $660 \pm 121$ & & & \\
\hline RES8S' upland & 32.6 & 32.5 & $342 \pm 70$ & & & & & & \\
\hline RES8S' interm. & 35.9 & 31.9 & $143 \pm 24$ & & & & & & \\
\hline RES8S'shoreline & 42.7 & 31.9 & $34 \pm 7$ & & & & & & \\
\hline RES4S upland & 26.7 & 28.6 & $326 \pm 20$ & 21.7 & 29.5 & $526 \pm 35$ & 18.1 & 31.1 & $232 \pm 50$ \\
\hline RES4S interm. up & & & & & & & 24.3 & 28.7 & $196 \pm 29$ \\
\hline RES4S interm. down & 26.0 & 34.2 & $168 \pm 28$ & 21.8 & 32.7 & $619 \pm 39$ & 35.1 & 29.8 & $443 \pm 67$ \\
\hline RES4S shoreline & 44.6 & 31.1 & $34 \pm 7$ & 18.3 & 32.1 & 115 & 51.2 & 29.6 & $393 \pm 57$ \\
\hline
\end{tabular}

At the six sites, fluxes were measured along the soil moisture gradient between the shoreline and the zone not impacted by the reservoir water-level fluctuation. Three to four sites with contrasting moisture content were selected at each site. At those six sites, fluxes were measured at 21 plots in total and $40 \mathrm{CO}_{2}$ fluxes were gathered, mostly in duplicates (from 1 to 4 replicates; Table 2). $\mathrm{CO}_{2}$ emissions were measured during three field campaigns in 2010, 2011 and 2013 using a stainless steel chamber (volume $12 \mathrm{~L}, 0.08 \mathrm{~m}^{2}$ ) described in Serça et al. (1994, 2016). At each site, two chambers were deployed in parallel and the collars were installed at least $1 \mathrm{~h}$ prior to measurement. Air samples were taken and stored with the same methodology as for bubbling samples every $15 \mathrm{~min}$ in each chamber before subsequent GC analysis. It has to be noted that soil studies and measurement of fluxes were restricted for safety reasons due to the high density of unexploded ordinances from the $60 \mathrm{~s}$ and $70 \mathrm{~s}$ in that area.

\section{Results}

\subsection{Temperature, oxygen, $\mathrm{pH}$, and organic and inorganic carbon in the Nam Theun watershed and carbon inputs to the reservoir}

In the rivers of the Nam Theun watershed, the water temperature was $24.5 \pm 0.2^{\circ} \mathrm{C}$ ranging from 13.5 to $32.0^{\circ} \mathrm{C}$ and $\mathrm{pH}$ was $6.83 \pm 0.03(4.75-8.95, n=405)$. The Nam On River was, on average, less oxygenated $(77 \pm 2 \%)$ than the others. It is characterized by the highest DOC concentrations $\left(222 \pm 11 \mu \mathrm{mol} \mathrm{L}{ }^{-1}, n=93\right)$, and amongst the highest $\mathrm{CO}_{2}$ concentrations $\left(59 \pm 6 \mu \mathrm{mol} \mathrm{L}{ }^{-1}, n=107\right)$ and the lowest TIC concentration ( $237 \pm 11 \mu \mathrm{mol} \mathrm{L}{ }^{-1}, n=107$; Fig. 2). The Nam Phao and the Nam Theun rivers are not significantly different in terms of POC, DOC, TIC and $\mathrm{CO}_{2}$ concentrations (Fig. 2). During the monitoring, the average DOC in the Nam Phao was $87 \pm 4 \mu \mathrm{mol} \mathrm{L}^{-1}(n=82)$ and $108 \pm 4 \mu \mathrm{mol} \mathrm{L}^{-1}(n=97)$ in the Nam Theun, that is more than 2 times lower than in the Nam On. TIC was $40 \%$ higher in the Nam Theun and Nam Phao rivers than in the Nam On (Nam Phao: $380 \pm 12 \mu \mathrm{molL}^{-1}, n=82$; Nam Theun: $379 \pm 15 \mu \mathrm{mol} \mathrm{L}-1, n=97$; Fig. 2). $\mathrm{CO}_{2}$ in the Nam Theun River $\left(54 \pm 5 \mu \mathrm{mol} \mathrm{L}^{-1}, n=105\right)$ and in the Nam Phao $\left(46 \pm 5 \mu \mathrm{mol} \mathrm{L}{ }^{-1}, n=86\right)$ contributed around 
CD
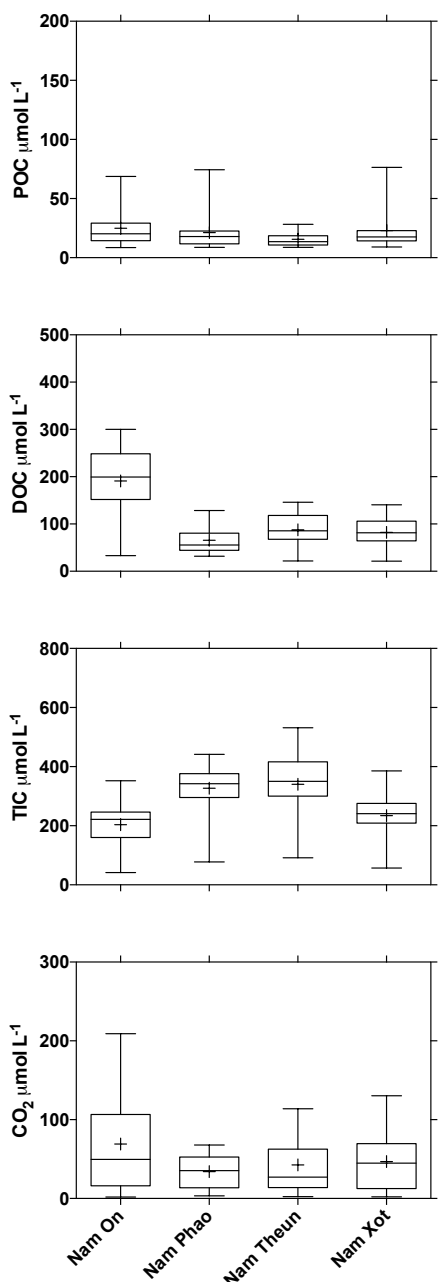

WD
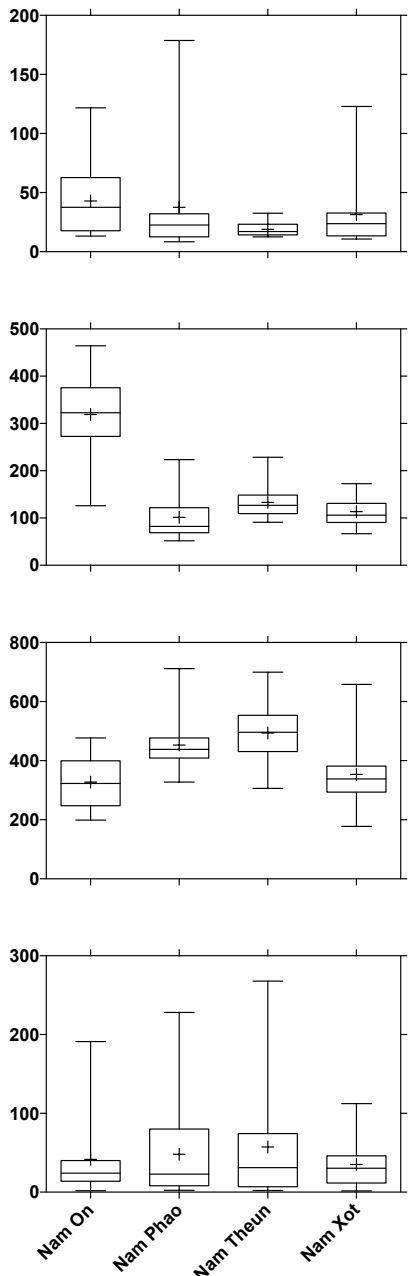

WW
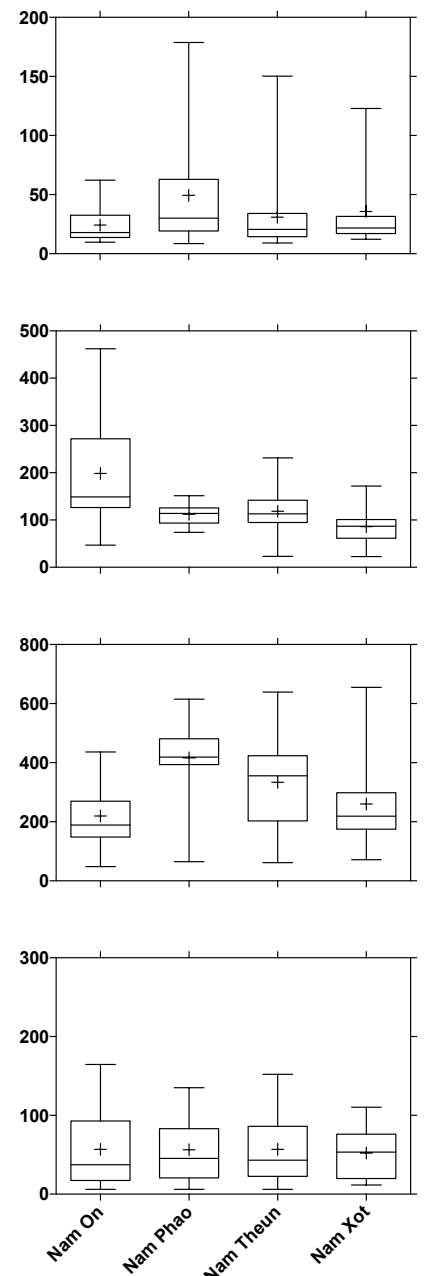

Figure 2. Median and interquartile ranges (boxes), average (+), and full range of values (whiskers) of particulate organic carbon (POC), dissolved organic carbon (DOC), total inorganic carbon (TIC) and $\mathrm{CO}_{2}$ concentrations in four pristine rivers of the Nam Theun watershed during three distinct seasons: cold dry (CD), warm dry (WD) and warm wet (WW) seasons. The dataset includes data from 2009 to 2013.

$15 \%$ of TIC whereas it was almost $25 \%$ in the Nam On. The Nam Xot River had amongst the lowest DOC $\left(90 \pm 3 \mu \mathrm{mol} \mathrm{L}^{-1}, n=93\right)$, TIC $\left(272 \pm 12 \mu \mathrm{mol} \mathrm{L}^{-1}, n=94\right)$ and $\mathrm{CO}_{2}\left(45 \pm 3 \mu \mathrm{mol} \mathrm{L}{ }^{-1}, n=110\right)$ concentrations (Fig. 2). Comparing results from all rivers, we could not find any significant differences in POC concentration. In all rivers during this monitoring, the average POC was $28 \pm 2 \mu \mathrm{mol} \mathrm{L}-1$ $(n=200)$ and contributed less than $20 \%$ of the TOC in this watershed (Fig. 2). We could not identify any clear seasonal pattern for POC, DOC, TIC and $\mathrm{CO}_{2}$ concentrations in the four rivers of the Nam Theun watershed (Fig. 2).

As reported in Descloux et al. (2016), the average total water discharge in the reservoir is $238 \mathrm{~m}^{3} \mathrm{~s}^{-1}$ ranging from $6 \mathrm{~m}^{3} \mathrm{~s}^{-1}$ during the WD seasons to $2061 \mathrm{~m}^{3} \mathrm{~s}^{-1}$ during the WW seasons. Carbon input to the reservoir as DOC,
POC and TIC ranged from $32.2 \pm 1.3 \mathrm{Gg} \mathrm{C} \mathrm{yr}^{-1}$ in 2010 to $46.2 \pm 1.5 \mathrm{Gg} \mathrm{C} \mathrm{yr}^{-1}$ in the wet year 2011 (Fig. 3). During the monitoring, TIC represented 60 to $70 \%$ of the carbon inputs to the reservoir (Fig. 3).

\subsection{Vertical profiles of temperature, $\mathrm{O}_{2}, \mathrm{pH}, \mathrm{CO}_{2}$ and organic carbon in the reservoir water column}

At the stations RES1-RES8, the typical vertical distributions of temperature, $\mathrm{O}_{2}$, DOC, $\mathrm{POC}$ and $\mathrm{CO}_{2}$ for the three seasons at various sampling stations are shown in Fig. 4. As already described in detail in Guérin et al. (2016), during the 4 years of monitoring, the reservoir water column was thermally stratified during the warm seasons with thermocline at $4.5 \pm 2.6$ and $5.8 \pm 4.8 \mathrm{~m}$ depths during the WD and WW seasons, respectively. As a consequence of thermal stratifica- 


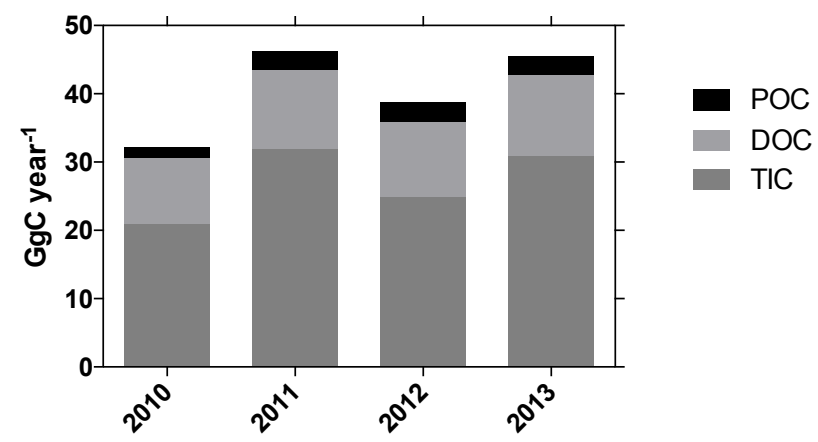

Figure 3. Total carbon inputs in the form of particulate organic carbon (POC), dissolved organic carbon (DOC) and total inorganic carbon (TIC) from the Nam Theun watershed to the Nam Theun 2 Reservoir for 4 distinct years after reservoir impoundment.

tion, the warm epilimnic waters are well oxygenated $(>80 \%$ saturation), whereas the hypolimnion is anoxic (Fig. 4). Occasionally, sporadic and local destratification occurred during high water inflow in the WW season. During the CD season, temperature and $\mathrm{O}_{2}$ decreased gradually with depth or $\mathrm{O}_{2}$ concentration was constant from the surface to the bottom of the water column (Fig. 4). After the power plant commissioning, the water column located near the turbine intake (RES9) got totally mixed as revealed by the homogeneous temperature and $\mathrm{O}_{2}$ profiles from the surface to the bottom (Fig. 4). pH always decreased from the surface to the bottom with, on average during the monitoring, surface $\mathrm{pH}=6.66 \pm 0.02(5.21-8.76, n=1316)$ and hypolimnic $\mathrm{pH}=6.15 \pm 0.01(4.88-8.00, n=1488)$.

Over the monitoring period at the stations RES1-RES8, the average $\mathrm{CO}_{2}$ concentration in the water column was $389 \pm 9 \mu \mathrm{mol} \mathrm{L}^{-1}$ and ranged from 0.3 to $4770 \mu \mathrm{mol} \mathrm{L}-1$ $(n=3698)$. It decreased from $544 \pm 24 \mu \mathrm{mol} \mathrm{L}^{-1}$ in 2010 to $154 \pm 9 \mu \mathrm{mol} \mathrm{L}^{-1}$ in 2013. During the WD and WW seasons, $\mathrm{CO}_{2}$ concentrations increased with water depth and often showed a maximum gradient at or just below the thermocline (Fig. 4). For the years 2010 to 2013, the average $\mathrm{CO}_{2}$ concentrations in the water column during the WD and WW seasons were always $50 \%$ higher than in the CD season (Fig. 4). DOC concentrations averaged $181 \pm 1 \mu \mathrm{mol} \mathrm{L}^{-1}$ and ranged from 12.5 to $569 \mu \mathrm{mol} \mathrm{L}^{-1}(n=3068)$. For the years 2010 , 2011 and 2012, we observed a significant decrease in DOC in the water column from year to year with average DOC concentrations of $208 \pm 3 \mu \mathrm{mol} \mathrm{L}^{-1}$ in $2010,190 \pm 3 \mu \mathrm{mol} \mathrm{L}^{-1}$ in 2011 and $177 \pm 2 \mu \mathrm{mol} \mathrm{L}^{-1}$ in 2012. In 2013, the DOC was not significantly lower than in $2012\left(175 \pm 2 \mu \mathrm{mol} \mathrm{L}^{-1}\right)$. From 2010 to 2013, DOC concentrations were about $25 \%$ higher in the WD and WW seasons than in the CD season. Whatever the year, the average epilimnic DOC concentration was $30 \%$ higher than in hypolimnic water. POC concentration was $63 \pm 2 \mu \mathrm{mol} \mathrm{L}^{-1}(n=2488)$. POC in hypolimnic waters $\left(92 \pm 3 \mu \mathrm{mol} \mathrm{L}^{-1}\right)$ was almost twice higher than in the epilimnion $\left(45 \pm 2 \mu \mathrm{mol} \mathrm{L}^{-1} ; p<0.0001, t\right.$ test $)$. The POC in the epilimnion decreased significantly from $41 \pm 4 \mu \mathrm{mol} \mathrm{L}^{-1}$ in 2010 to $23 \pm 2 \mu \mathrm{mol} \mathrm{L}^{-1}$ in 2013 in the epilimnion $(p<0.0001)$. POC in hypolimnic waters did not show any consistent trend with yearly average values being $87 \pm 6 \mu \mathrm{mol} \mathrm{L}^{-1}$ in $2010,67 \pm 6 \mu \mathrm{mol} \mathrm{L}^{-1}$ in 2011 , $104 \pm 7 \mu \mathrm{mol} \mathrm{L}^{-1}$ in the wet year 2012 and $83 \pm 5 \mu \mathrm{mol} \mathrm{L}^{-1}$ in 2013. No clear seasonal variation was observed.

At the station RES9 where the presence of the water intake enhances vertical mixing of the water column leading to the transport of bottom water to the surface, the water column is not thermally stratified and always oxygenated from the surface to the bottom after the reservoir was commissioned in April 2010 (Guérin et al., 2016; Fig. 4). Since commissioning, $\mathrm{O}_{2}$ saturation was $60 \pm 2 \%$ over the water column. The water column was significantly more oxygenated during the overturn in the $\mathrm{CD}(74 \pm 3 \%)$ than in the WW and WD seasons $(56 \pm 2 \% ; p<0.0001$, $t$ test) and significantly more oxygenated $(p<0.0001)$ in the wet year $2011(70 \pm 3 \%$ on average) than in 2010 and $2012(56 \pm 3 \%$ on average). In 2013, which was an average hydrological year, the water column was well oxygenated with $71 \pm 1 \%$ suggesting of improvement of the water quality. $\mathrm{CO}_{2}$ concentrations were almost constant from the surface to the bottom and averaged $216 \pm 13 \mu \mathrm{mol} \mathrm{L}{ }^{-1}$ over the whole monitoring period $(n=512$; Fig. 4). $\mathrm{CO}_{2}$ concentration in the water column decreased from $311 \pm 32 \mu \mathrm{mol} \mathrm{L}^{-1}$ in 2010 down to $28 \pm 2 \mu \mathrm{mol} \mathrm{L}^{-1}$ in 2013. Concentrations in the WW and WD seasons were similar $204 \pm 14 \mu \mathrm{mol} \mathrm{L}^{-1}$ and more than 2 times higher than during the CD season $\left(105 \pm 6 \mu \mathrm{mol} \mathrm{L}^{-1}\right)$. POC concentration was $25 \pm 1 \mu \mathrm{mol} \mathrm{L}^{-1}(n=431)$ and DOC was $157 \pm 2 \mu \mathrm{mol} \mathrm{L}^{-1}(n=642)$ over the whole water column and both follow the same seasonal and temporal variations as described for the other stations.

\subsection{Reservoir surface $\mathrm{CO}_{2}$ concentration and diffusive fluxes}

The reservoir surface $\mathrm{CO}_{2}$ concentrations $(n=1067)$ ranged from 0.3 to $970 \mu \mathrm{mol} \mathrm{L}^{-1}$ (Fig. 5a, b) and diffusive fluxes ranged from -40.4 up to $2694.9 \mathrm{mmol} \mathrm{m}^{-2} \mathrm{~d}^{-1}$ (Fig. 5c, d). Most of the dataset (85\% of all measurements) showed $\mathrm{CO}_{2}$ supersaturation with respect to the atmosphere. In 2009 (from May to December), surface concentrations and diffusive fluxes from all nine sampling stations located in the reservoir were statistically similar ( $p>0.05$, ANOVA test). The average surface concentration was $68.2 \pm 47.9 \mu \mathrm{mol} \mathrm{L}^{-1}$ and the diffusive flux was $101.6 \pm 137.7 \mathrm{mmol} \mathrm{m}^{-2} \mathrm{~d}^{-1}$.

From 2010 to 2013 at the stations RES1 to RES8, the yearly average surface $\mathrm{CO}_{2}$ concentrations decreased significantly from $62.7 \pm 3.6$ to $32.7 \pm 3.2 \mu \mathrm{mol} \mathrm{L}^{-1}$, while diffusive fluxes decreased from $89.8 \pm 10$ to $13.7 \pm 4.7 \mathrm{mmol} \mathrm{m}^{-2} \mathrm{~d}^{-1}$ without any significant spatial variations ( $p>0.05$, ANOVA test). Over the 2010-2012 


\section{Cool dry}

RES3

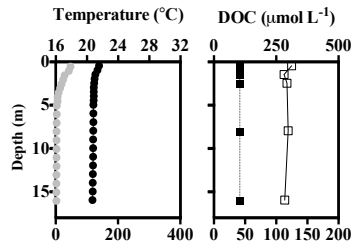

RES7

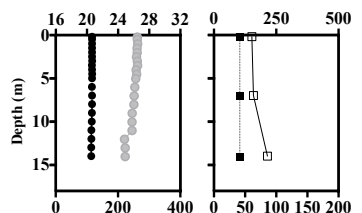

RES9

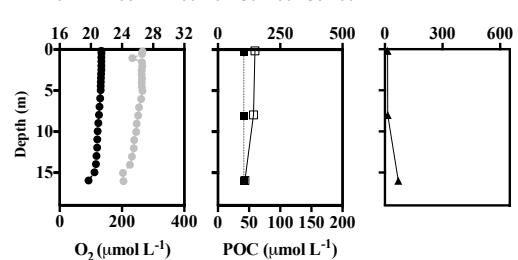

Warm dry

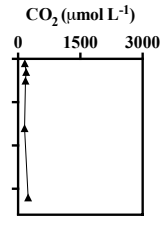

\begin{tabular}{l}
$0 \quad 500$ \\
\hline
\end{tabular} 10001500

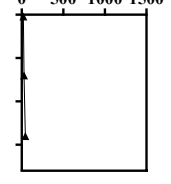

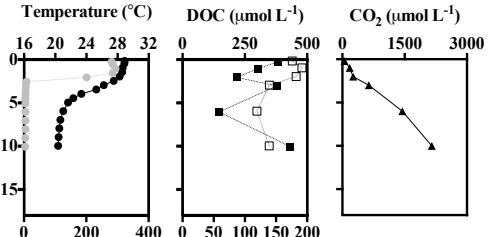
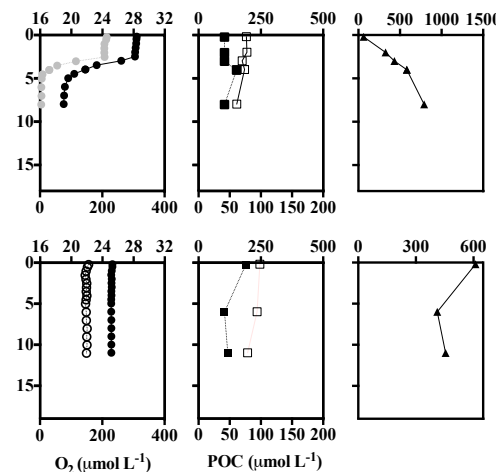

Warm wet
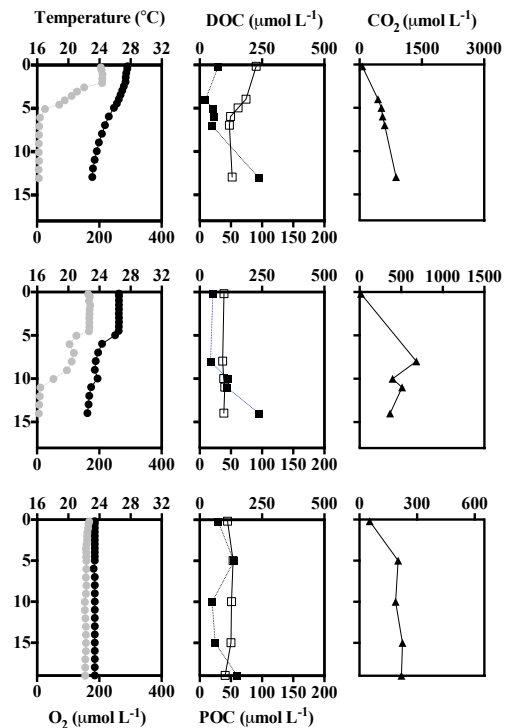

Figure 4. Temperature (grey solid circle) and oxygen (black solid circle), DOC (open square) and $\mathrm{POC}$ (solid square), and $\mathrm{CO}_{2}$ (triangle) concentrations in the Nam Theun 2 Reservoir water column during the cool dry (CD), warm dry (WD) and warm wet (WW) seasons in 2011 at three stations (RES3, RES7 and RES9).

period, the highest concentration and fluxes were always observed in the WD season $\left(70 \pm 3 \mu \mathrm{mol} \mathrm{L}^{-1}\right.$ and $\left.90 \pm 9 \mathrm{mmol} \mathrm{m}^{-2} \mathrm{~d}^{-1}\right)$, they decreased down to $51 \pm 3 \mu \mathrm{mol} \mathrm{L}^{-1}$ and $65 \pm 8 \mathrm{mmol} \mathrm{m}^{-2} \mathrm{~d}^{-1}$ in the WW and reached their minima in the $\mathrm{CD}$ season $\left(45 \pm 3 \mu \mathrm{mol} \mathrm{L}^{-1}\right.$ and $22 \pm 2 \mathrm{mmol} \mathrm{m}^{-2} \mathrm{~d}^{-1}$ ) (Fig. 5a, c). In 2013, the reservoir was a net $\mathrm{CO}_{2}$ sink from March to August $\left(-11 \pm 2 \mathrm{mmol} \mathrm{m}^{-2} \mathrm{~d}^{-1}, n=96\right)$ and emissions in the CD season were $66 \pm 9 \mathrm{mmol} \mathrm{m}^{-2} \mathrm{~d}^{-1}(n=41)$ that is 3 times higher than usually observed for that season.

At the water intake (RES9) after the commissioning, surface concentrations and diffusive fluxes were statistically different from the other stations and were significantly higher as already observed for $\mathrm{CH}_{4}$ (Guérin et al., 2016). The average surface $\mathrm{CO}_{2}$ concentrations at RES9 were $287 \pm 350$ and $184 \pm 234 \mu \mathrm{mol} \mathrm{L}^{-1}$ for the year 2010 and 2011, respectively that is 3- to 5-fold higher than the average at the other stations (Fig. 5b). In 2012, surface $\mathrm{CO}_{2}$ concentrations at RES9 dropped down to $65 \pm 23 \mu \mathrm{mol} \mathrm{L}{ }^{-1}$, still almost twice the concentration at the other stations. In 2013, surface concentration at RES9 was not statistically different than at the other station in the reservoir $\left(33 \pm 4 \mu \mathrm{mol} \mathrm{L}^{-1}\right.$ in 2013). On an annual basis, the diffusive fluxes at RES9 decreased from an average of $745 \pm 195$ to $18 \pm 9 \mathrm{mmol} \mathrm{m}^{-2} \mathrm{~d}^{-1}$ between 2010 and 2013 (Fig. 5d). The same seasonality as described before was observed at RES9 with an exacerbated effect at the transition between the WD and WW seasons since diffu- sive fluxes were then up to 17 -fold higher than the average fluxes at the other stations for that same period (Fig. 5c, d).

Monthly emissions by diffusive fluxes varied by 2 orders of magnitude between 2009 and 2012. Superimposed on the general decrease in emissions with time, we observed very significant seasonal variations with emissions peaking during the transition between the WD and WW seasons, even though the reservoir water surface was at its minimum (Fig. 5e). The annual diffusive $\mathrm{CO}_{2}$ emission from the reservoir was $730.0 \pm 46.2 \mathrm{Gg}\left(\mathrm{CO}_{2}\right) \mathrm{yr}^{-1}$ in 2009 and dropped down by a factor of 6 in $2013\left(118 \pm 11.5 \mathrm{Gg}\left(\mathrm{CO}_{2}\right) \mathrm{yr}^{-1}\right.$; Fig. 5f).

\section{4 $\mathrm{O}_{2}, \mathrm{pH}$, organic carbon and $\mathrm{CO}_{2}$ downstream of the reservoir}

After the commissioning, immediately downstream of the power station (station TRC1), the average $\mathrm{O}_{2}$ concentration was $174 \pm 58 \mu \mathrm{mol} \mathrm{L}^{-1}$, that is, $67 \pm 20 \%$ saturation $(n=189)$ and $\mathrm{pH}$ was $6.55 \pm 0.04(n=234)$. Further downstream, the $\mathrm{O}_{2}$ concentration always increased and the $\mathrm{O}_{2}$ saturation downstream of station DCH4 located $30 \mathrm{~km}$ from the turbines was always around $100 \%$ saturation in the artificial downstream channel (average $100.4 \%, n=146$ ). Just below the regulating dam, in the Nam Kathang River (NKT3), the average $\mathrm{O}_{2}$ concentration was $237 \mu \mathrm{mol} \mathrm{L}^{-1}$, that is, $93 \%$ saturation $(n=120)$. There was no marked interannual change in the $\mathrm{O}_{2}$ concentration. At $\mathrm{DCH} 4, \mathrm{pH}$ increased to $7.17 \pm 0.04(n=186)$. 

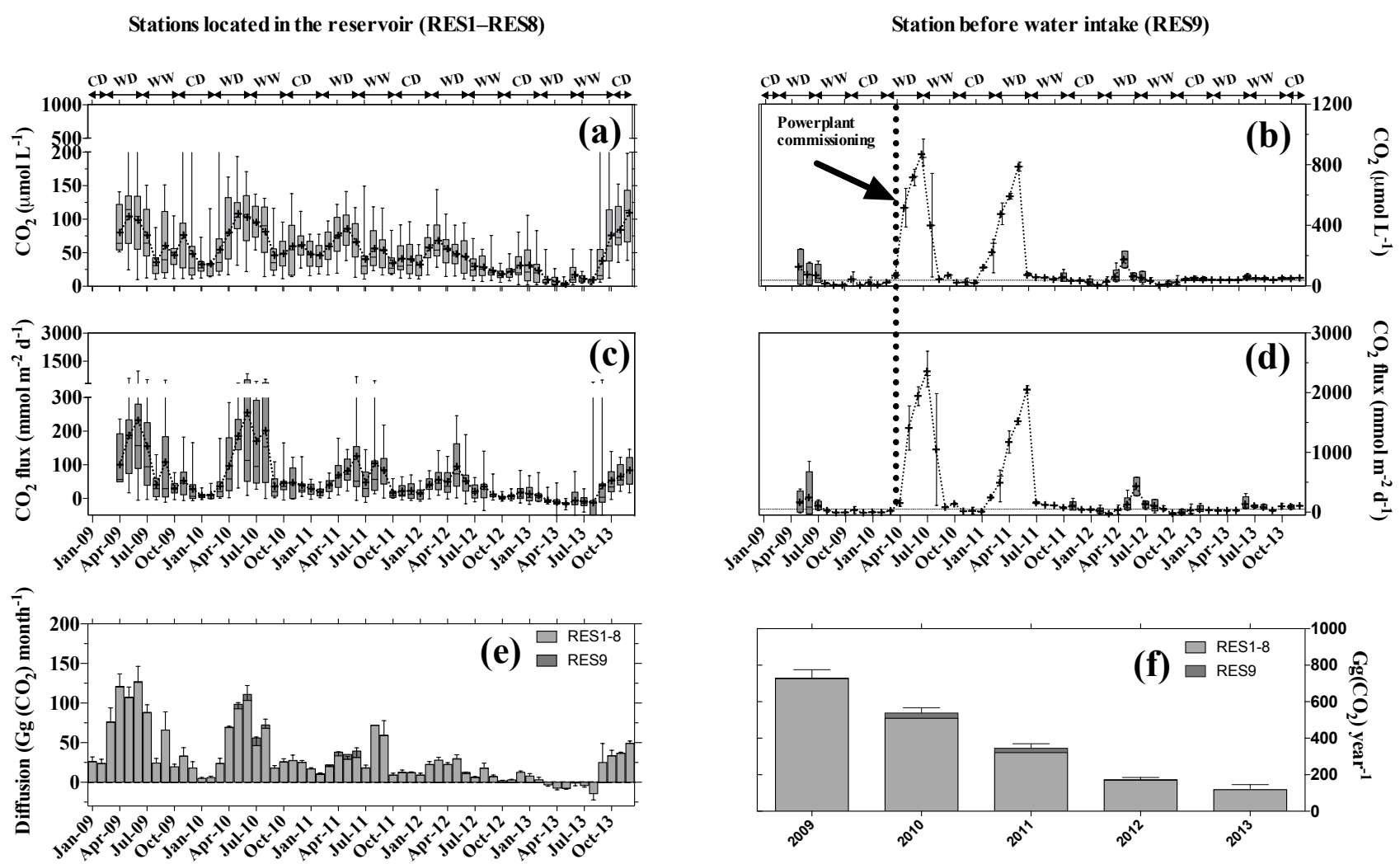

Figure 5. Monthly average $\mathrm{CO}_{2}$ concentrations at the stations RES1-8 (a) and at the station RES9 (b), average diffusive fluxes at the stations RES1-8 (c) and at the station RES9 (d) and total monthly (e) and yearly (f) $\mathrm{CO}_{2}$ emissions by diffusive fluxes from the Nam Theun 2 Reservoir (Lao PDR).

On average at all the stations in between TRC1 and DCH4, DOC concentration was $159 \pm 2 \mu \mathrm{mol} \mathrm{L}^{-1}(n=1366)$ over all stations for all years between 2009 and 2013. DOC decreased from $187 \pm 2 \mu \mathrm{mol} \mathrm{L}^{-1}$ in $2010(n=272)$ to $157 \pm 2 \mu \mathrm{mol} \mathrm{L}^{-1}$ in $2013(n=303)$. Average POC was $25 \pm 1 \mu \mathrm{mol} \mathrm{L}^{-1}(n=818)$ for all years between 2009 and 2013, and followed interannual variations already observed for the reservoir, i.e. higher POC concentration in the WW season of 2012.

$\mathrm{CO}_{2}$ concentration below the Powerhouse (TRC1), which receives water from the station RES9 in the reservoir after the water transiting through the turbines, varied by almost 3 orders of magnitude, ranging from 1.4 to $856 \mu \mathrm{mol} \mathrm{L}^{-1}$ with an average of $153 \pm 14 \mu \mathrm{mol} \mathrm{L}^{-1}(n=199)$. The $\mathrm{CO}_{2}$ concentrations varied seasonally with maximum concentrations at the end of the WD season, and minimum at the end of the $\mathrm{CD}$ season. Below the powerhouse, along the longitudinal transects from TRC1 to $\mathrm{DCH} 4$, surface $\mathrm{CO}_{2}$ concentration decreased by a factor of 3 within a distance of $30 \mathrm{~km}$ during the WD and WW seasons (from $267 \pm 34$ to $90 \pm 10 \mu \mathrm{mol} \mathrm{L}^{-1}$ and from $235 \pm 28$ to $70 \pm 8 \mu \mathrm{mol} \mathrm{L}{ }^{-1}$, respectively for $\mathrm{WD}$ and $\mathrm{WW})$. In the $\mathrm{CD}$ season when $\mathrm{CO}_{2}$ concentrations were lower, the decrease in concentra- tion with distance from the dam was only by a factor of 2 (from $49 \pm 8$ to $30 \pm 4 \mu \mathrm{mol} \mathrm{L}^{-1}$ ). Between 2010 and 2013 for all stations in the downstream channel (TRC1 to DCH4), annual average $\mathrm{CO}_{2}$ concentrations decreased by a factor of 7 from $182 \pm 9 \mu \mathrm{mol} \mathrm{L}^{-1}$ to $24 \pm 2 \mu \mathrm{mol} \mathrm{L}^{-1}$. On average, $\mathrm{CO}_{2}$ concentration reached down to $56 \pm 5 \mu \mathrm{mol} \mathrm{L}{ }^{-1}$ at DCH4, which is in the same order of magnitude as the concentrations found in the pristine Xe Bangfai River (XBF1, $60 \pm 2 \mu \mathrm{mol} \mathrm{L}^{-1}, n=64$ ), Nam Kathang Noy River (NKT1, $35 \pm 3 \mu \mathrm{mol} \mathrm{L}^{-1}, n=47$ ) and Nam Kathang Gnai River (NKT2, $82 \pm 10 \mu \mathrm{mol} \mathrm{L}^{-1}, n=70$ ).

Immediately downstream of the Nakai Dam (NTH3) after the commissioning, the average $\mathrm{O}_{2}$ concentration was $224 \mu \mathrm{mol} \mathrm{L}^{-1}$, that is $87 \%$ saturation $(n=73)$, and the concentration increased further downstream. $\mathrm{pH}$ was $6.84 \pm 0.06 \quad(n=166)$. Average DOC concentration was $166 \pm 2 \mu \mathrm{mol} \mathrm{L}^{-1}(n=653)$ and decreased from $197 \pm 4 \mu \mathrm{mol} \mathrm{L}^{-1}$ in $2010(n=147)$ to $162 \pm 3 \mu \mathrm{mol} \mathrm{L}-1$ $(n=127)$ in 2013. The average POC concentration was $50 \pm 5 \mu \mathrm{mol} \mathrm{L}^{-1}(n=7)$ and $\mathrm{CO}_{2}$ concentration was $67 \pm 9 \mu \mathrm{mol} \mathrm{L}^{-1}(n=77)$. The $\mathrm{CO}_{2}$ concentration decreased by a factor of $2(40 \pm 5 \mu \mathrm{mol} \mathrm{L}-1, n=54)$ within the next $10 \mathrm{~km}$ below the dam (down to NTH4, Fig. 1), where pH was 

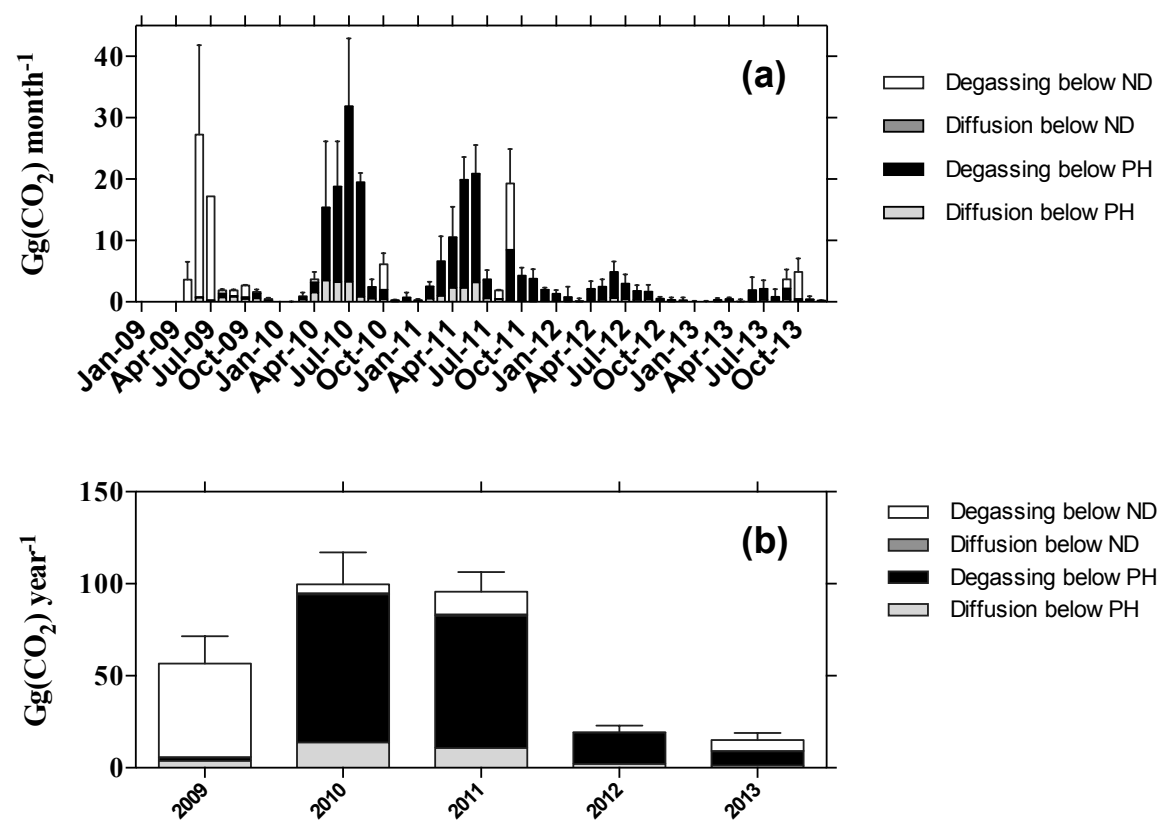

Figure 6. Diffusive fluxes and degassing below the powerhouse (PH) and the Nakai Dam (ND) on a monthly (a) and yearly basis (b) at the Nam Theun 2 Reservoir (Lao PDR). Note that degassing below ND includes spillway release (main contributor to 2009 and 2011 emissions below ND). Degassing below the powerhouse includes degassing immediately downstream of the turbines, downstream of the regulation dam and downstream of the aeration.

$7.19 \pm 0.06(n=97)$. At NTH4, the observed concentrations were in the same order of magnitude as the concentrations in the pristine rivers in the same watershed $\left(53 \pm 6 \mu \mathrm{mol} \mathrm{L}^{-1}\right.$ at NPH1 in the Nam Phao River, $n=59$ ).

\section{5 $\mathrm{CO}_{2}$ emissions downstream of the reservoir}

After the commissioning, the annual average diffusive fluxes downstream of the powerhouse decreased from $482 \pm 603 \mathrm{mmol} \mathrm{m}^{-2} \mathrm{~d}^{-1}$ in the year $2010(-32-$ $\left.33762 \mathrm{mmol} \mathrm{m}^{-2} \mathrm{~d}^{-1}\right)$ to $32 \pm 8 \mathrm{mmol} \mathrm{m}^{-2} \mathrm{~d}^{-1} \quad(-39-$ $216 \mathrm{mmol} \mathrm{m}^{-2} \mathrm{~d}^{-1}$ ) in 2013 (not shown). They followed the same seasonal dynamics as the $\mathrm{CO}_{2}$ concentrations and they decrease with the distance from the powerhouse. Total emissions by diffusion from the downstream channel decreased from $14 \pm 12 \mathrm{Gg}\left(\mathrm{CO}_{2}\right) \mathrm{yr}^{-1}$ in 2010 to $1.3 \pm 0.5 \mathrm{Gg}\left(\mathrm{CO}_{2}\right) \mathrm{yr}^{-1}$ in 2013 (Fig. 6a). Degassing in the whole downstream channel (including degassing below the turbines, the regulating pond and the aeration weir) reached up to $28.5 \mathrm{Gg}\left(\mathrm{CO}_{2}\right)$ month $^{-1}$ just after the commissioning of the reservoir when the water was released for the first time (Fig. 6a). During the monitoring, 60-90\% of the annual degassing occurred within 3-4 months of transition between the WD and WW seasons corresponding to the seasons when the hypolimnic waters were the most enriched in $\mathrm{CO}_{2}$ (Fig. 6a). Total degassing decreased from $80 \pm 36 \mathrm{Gg}\left(\mathrm{CO}_{2}\right) \mathrm{yr}^{-1}$ in 2010 to $8 \pm 4 \mathrm{Gg}\left(\mathrm{CO}_{2}\right) \mathrm{yr}^{-1}$ in 2013 (Fig. 6b).
Disregarding periods of spillway releases from April to June 2009 for water-level regulation and in SeptemberOctober 2011 during the flood, degassing downstream of the Nakai Dam (up to $0.48 \mathrm{Gg}\left(\mathrm{CO}_{2}\right)$ month $^{-1}$ ) is usually 10 times lower than degassing in the downstream channel because of (1) the low continuous water discharge at the Nakai Dam $\left(2 \mathrm{~m}^{3} \mathrm{~s}^{-1}\right)$ and (2) the withdrawal of the water from the reservoir epilimnion (Deshmukh et al., 2016; Fig. 6a). However, during the use of spillways for waterlevel regulation in the reservoir, degassing reached up to $26 \mathrm{Gg}\left(\mathrm{CO}_{2}\right)$ month $^{-1}$ in 2009 before the commissioning and 4 to $10 \mathrm{Gg}\left(\mathrm{CO}_{2}\right)$ month $^{-1}$ during the occasional uses in October 2010 and September 2011 (Fig. 6a). As determined from the longitudinal profiles of $\mathrm{CO}_{2}$ concentrations downstream of the dam, diffusive emissions from the Nam Theun River that are actually attributable to the NT2R occurred within the first $10 \mathrm{~km}$ below the dam as it was also the case for $\mathrm{CH}_{4}$ (Deshmukh et al., 2016). The annual average diffusive $\mathrm{CO}_{2}$ fluxes were $126 \pm 137$ and $288 \pm 346 \mathrm{mmol} \mathrm{m}^{-2} \mathrm{~d}^{-1}$ in 2010 and 2011 , respectively. The annual average diffusive $\mathrm{CO}_{2}$ flux was 1 order of magnitude lower in 2013 ( $24 \pm 68 \mathrm{mmol} \mathrm{m}^{-2} \mathrm{~d}^{-1}$; not shown). The total emissions by diffusion and degassing resulting from these fluxes ranged between $5.5 \pm 0.1 \mathrm{Gg}\left(\mathrm{CO}_{2}\right) \mathrm{yr}^{-1}$ in 2010 and $0.14 \pm 0.06 \mathrm{Gg}\left(\mathrm{CO}_{2}\right) \mathrm{yr}^{-1}$ in 2013 (Fig. 6b).

On a yearly basis, emissions downstream of NT2R decreased from $99.7 \pm 25.3$ to $15.0 \pm 6.5 \mathrm{Gg}\left(\mathrm{CO}_{2}\right) \mathrm{yr}^{-1}$ between 2010 and 2013 (Fig. 6b). Before the reservoir com- 


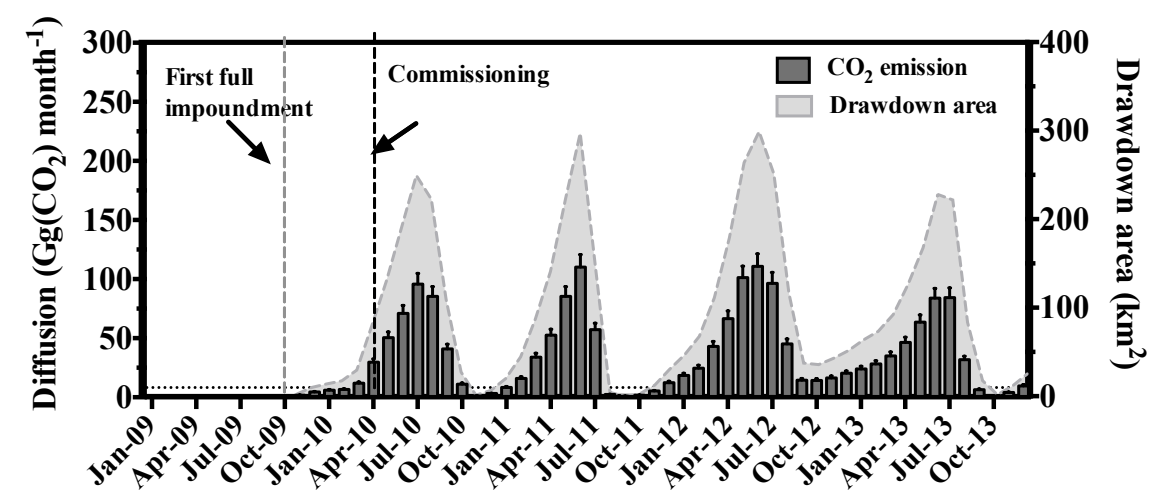

Figure 7. Monthly emissions from the drawdown area and variation in the area of the drawdown of the Nam Theun 2 Reservoir (Lao PDR).

missioning in 2009, emissions were dominated by degassing due to spillway releases. After the commissioning, emissions were dominated by degassing in the downstream channel which contributed $80-90 \%$ of total downstream emissions.

\section{6 $\mathrm{CO}_{2}$ bubbling}

The $\mathrm{CO}_{2}$ content in the sampled bubbles was $0.29 \pm 0.37 \%$ $(n=2334)$. On average, the $\mathrm{CO}_{2}$ bubbling was 0.16 $\pm 0.24 \mathrm{mmol} \mathrm{m}^{-2} \mathrm{~d}^{-1}\left(0-2.8 \mathrm{mmol} \mathrm{m}^{-2} \mathrm{~d}^{-1}\right)$ for depths shallower than $16 \mathrm{~m}$. Considering the water surface variations, the monthly ebullitive $\mathrm{CO}_{2}$ emissions ranged from $0.04 \pm 0.06$ to $0.11 \pm 0.16 \mathrm{Gg}\left(\mathrm{CO}_{2}\right)$ month $^{-1}$. $\mathrm{CO}_{2}$ bubbling was constant around $1.1 \pm 2.2 \mathrm{Gg}\left(\mathrm{CO}_{2}\right) \mathrm{yr}^{-1}$ throughout the monitoring.

\section{7 $\mathrm{CO}_{2}$ emissions from the drawdown area}

Four types of pristine soils were identified in the six different studied catenae. Acrisols were the most represented soils and were found at three sites (RES4S, RES8S and RES8'S; Table 1). In the area with dense forest, soils were characterized as plinthosol (RES3S) and plinthic ferralsol (RES2S) and the pedological cover at the NNR (Nam Nien River) site belong to planosol type soil (Table 1). At all sites, from upland pristine soils to the shoreline, stagnic properties were more and more pronounced. Average organic carbon content $(\% \mathrm{C})$, nitrogen $(\% \mathrm{~N})$ and $\mathrm{C}: \mathrm{N}$ ratio were $1.84 \pm 0.10 \%$, $0.14 \pm 0.01 \%$ and $12.83 \pm 0.30$, in surface horizons, respectively. For those three parameters, no statistical differences were obtained according to soil type, topography or measurement site. Diffusive $\mathrm{CO}_{2}$ fluxes ranged between $34 \pm 7$ and $699 \pm 59 \mathrm{mmol} \mathrm{m}^{-2} \mathrm{~d}^{-1}$ (Table 2). The fluxes were not significantly correlated with the surface moisture (17.5 to $51.2 \%)$ and temperature $\left(18.1\right.$ to $34.2{ }^{\circ} \mathrm{C}$; Table 2$)$. The fluxes neither varied significantly with soil types, topography, measurement sites, nitrogen content or $\mathrm{C}: \mathrm{N}$ ratio ( $p>0.05$, ANOVA test). However, average fluxes at each site were significantly correlated with the average $\mathrm{C}$ con- tent $(p=0.0452)$. Since we did not observe significant spatial variations related to topography, humidity or temperature that could have been considered for refined spatial and temporal extrapolation, we further consider the average of all fluxes that is $279 \pm 27 \mathrm{mmol} \mathrm{m}^{-2} \mathrm{~d}^{-1}$ throughout the years.

After the commissioning of the reservoir, emissions varied by 3 orders of magnitude. Since a constant $\mathrm{CO}_{2}$ emission is accounted for, the seasonal pattern of $\mathrm{CO}_{2}$ emission from the drawdown mimics the variation of the surface of that area (Fig. 7). Monthly $\mathrm{CO}_{2}$ emissions have reached up to $110.8 \pm 10.7 \mathrm{Gg}\left(\mathrm{CO}_{2}\right)$ month $^{-1}$ by the end of the WD season when drawdown area reached its maximum, whereas it decreased down to $0.6 \pm 0.1 \mathrm{Gg}\left(\mathrm{CO}_{2}\right)$ month $^{-1}$ at the end of the WW season when drawdown area reached its minimum (Fig. 7). Around 80-90\% of the annual emissions occurred within 4-6 months of the transition period between the WD and WW seasons (Fig. 7) when the drawdown area surface is at its maximum. The lowest emissions from the drawdown area occurred during the wet year 2011 $\left(386 \pm 16 \mathrm{Gg}\left(\mathrm{CO}_{2}\right) \mathrm{yr}^{-1}\right)$ and the highest emissions during the dry year $2012\left(572 \pm 20 \mathrm{Gg}\left(\mathrm{CO}_{2}\right) \mathrm{yr}^{-1}\right)$. On average from 2009 to 2013, emissions from the drawdown area were $431 \pm 42 \mathrm{Gg}\left(\mathrm{CO}_{2}\right) \mathrm{yr}^{-1}$.

\section{Discussion}

\section{1 $\mathrm{CO}_{2}$ dynamics in the NT2R water column and downstream rivers}

The dynamics of $\mathrm{CO}_{2}$ in the NT2R is highly dependent on the hydrology and hydrodynamics of the reservoir as it has already been described for $\mathrm{CH}_{4}$ (Guérin et al., 2016). During the warm seasons (WD and WW) when the water column is thermally stratified, the vertical profiles of $\mathrm{CO}_{2}$ concentration in the water column are similar to profiles obtained in other tropical or subtropical reservoirs (Abril et al., 2005; Guérin et al., 2006; Chanudet et al., 2011; Kemenes et al., 2011), but also boreal reservoirs (Demarty et al., 2011). The 
high concentrations measured in the hypolimnion suggest that the main source of $\mathrm{CO}_{2}$ is located at the bottom and very likely in the flooded soils, vegetation and sediments, whereas the decrease in $\mathrm{CO}_{2}$ toward the surface suggest both consumption by primary production and/or loss to the atmosphere (Galy-Lacaux et al., 1997b; St Louis et al., 2000; Abril et al., 2005; Guérin et al., 2008; De Junet et al., 2009; Barros et al., 2011; Chanudet et al., 2011; Teodoru et al., 2011). In the CD season, after the reservoir overturn, the average $\mathrm{CO}_{2}$ concentration in the reservoir water column decreases sharply (by $50 \%$ on average) and $\mathrm{CO}_{2}$ concentration increases regularly from the surface to the bottom of the water column. However, no $\mathrm{CO}_{2}$ burst was observed at the beginning of the $\mathrm{CD}$ season, evidence that reservoir overturn has only a moderate impact on $\mathrm{CO}_{2}$ emissions. This assumption is reinforced by the fact that during the same sampling, hot moments of $\mathrm{CH}_{4}$ emissions that should have occurred at the same time were captured (Guérin et al., 2016). As observed in most tropical and subtropical reservoirs, the higher concentrations were observed during the warm seasons due to long residence time of water and warmer conditions enhancing $\mathrm{CO}_{2}$ build-up (Abril et al., 2005; Chanudet et al., 2011; Kemenes et al., 2011), whereas the lowest were found after reservoir overturn when the water outgassed (Chanudet et al., 2011). A significant shift in the carbon biogeochemical cycling occurred in the reservoir in 2013 with the reservoir water surface becoming a $\mathrm{CO}_{2}$ sink during the WD season and the beginning of the WW season (from March to August). Although no major change was observed in nutrient concentrations, the number of phytoplanktonic cells was $50 \%$ higher in 2013 than 2012 (Maud Cottet, personal communication, 2017) indicating that primary production was significantly enhanced in 2013. Despite the fact that the reservoir was a sink for the 6 months when $\mathrm{CO}_{2}$ emissions are usually the highest of the year, annual $\mathrm{CO}_{2}$ emissions at the surface of the reservoir were only $50 \%$ lower in 2013 than in 2012. In 2013, $\mathrm{CO}_{2}$ was mainly emitted in the $\mathrm{CD}$ after the period of high biological productivity suggesting that the degradation of autochthonous $\mathrm{OM}$ fuels $\mathrm{CO}_{2}$ emissions.

The maximum concentration and the highest $\mathrm{CO}_{2}$ stock in the water column highly depend on the age of the reservoir. In the NT2R, average $\mathrm{CO}_{2}$ concentration was 3 times higher in 2010 than in 2013 and the maximum concentrations in 2010 was almost 2 times higher than in $2013\left(4771 \mu \mathrm{mol} \mathrm{L}^{-1}\right.$ in 2010 vs. $2649 \mu \mathrm{mol} \mathrm{L}^{-1}$ in 2013). Those high concentrations are slightly lower than the maximum concentration measured in the hypolimnion of the Petit Saut Reservoir less than a year after it was flooded (Galy-Lacaux et al., 1997a; Abril et al., 2005). Disregarding these high concentrations observed in the hypolimnion of the reservoir at the end of the WD season and beginning of the WW season in 2009 and 2010, the $\mathrm{CO}_{2}$ concentrations in the NT2R are in the same range as concentrations in other older reservoirs in the tropics or the subtropics (Abril et al., 2005; Guérin et al., 2006; Chanudet et al., 2011; Kemenes et al., 2011). This decrease during the first 4 years after impoundment is very consistent with the decrease in the $\mathrm{CO}_{2}$ concentration with the reservoir age as already observed at the Petit Saut Reservoir (Abril et al., 2005), at the Eastmain I Reservoir (Teodoru et al., 2012) or over a multi-site study (Barros et al., 2011).

Disregarding the station RES9 located at the water intake, no significant spatial variation in $\mathrm{CO}_{2}$ surface concentrations was found despite very significant differences in hypolimnic concentration between stations located upstream of the Nakai Dam (RES1, 2 and 3) and stations located in areas close to the three main tributaries (RES6, 7 and 8). The average hypolimnic concentrations at the stations RES1-3 were 2 times higher than at the stations RES6-8. This difference is attributed to both (1) the difference in carbon density at the bottom of the reservoir in those two contrasted areas in terms of submerged ecosystems (Descloux et al., 2011; see Sect. 4.3) and (2) the difference in terms of water residence time between those two zones (Guérin et al., 2016). Stations RES13 are located in areas with the longest water residence time in the reservoir since the water mostly enters the reservoir in the RES6-8 area from the Nam Theun, Nam Noy and Nam On rivers before being delivered to the water intake (close to RES9) on the opposite side of NT2R, which has a narrow and elongated shape (Fig. 1). Therefore, the water renewal in the RES6-9 area is high and $\mathrm{CO}_{2}$ accumulates less in the water column confirming the importance of the reservoir hydrology on the spatial variability in dissolved gases in reservoirs (Pacheco et al., 2015; Guérin et al., 2016).

As found for $\mathrm{CH}_{4}$, the main factor influencing the spatial variability of $\mathrm{CO}_{2}$ in the water column is the vertical mixing of the water column induced by the water intake located close to RES9 (Deshmukh et al., 2016; Guérin et al., 2016). The design of the water intake enhances horizontal water current velocities and vertical mixing which lead to the transport of bottom waters to the surface. As a consequence, surface concentrations at RES9 were up to 30 times higher than at other stations in 2010 and 2011 (Fig. 5b). With the significant decrease in concentrations in 2012 and 2013, the difference with other stations dropped to a factor of 4 . These maximum surface concentrations at RES9 are up to 10 times higher than concentrations found in other tropical reservoirs in South America (Abril et al., 2005; Guérin et al., 2006; Kemenes et al., 2011) and Lao PDR (Chanudet et al., 2011) showing that, as for $\mathrm{CH}_{4}, \mathrm{CO}_{2}$ emissions can be enhanced upstream of water intakes or dams.

Downstream of the reservoir in the Nam Theun River or the artificial channel, $\mathrm{CO}_{2}$ concentrations follow the same seasonality as in the reservoir. Concentrations peak in JuneJuly at the transition between the WD and WW seasons, and reach their minima in the CD season. Downstream of the Nakai Dam, the concentrations are twice lower than downstream of the powerhouse since mostly epilimnic water from the RES1 station is transferred downstream of the dam. Within less than $10 \mathrm{~km}$ further downstream, concentrations are not significantly different than in pristine rivers of 


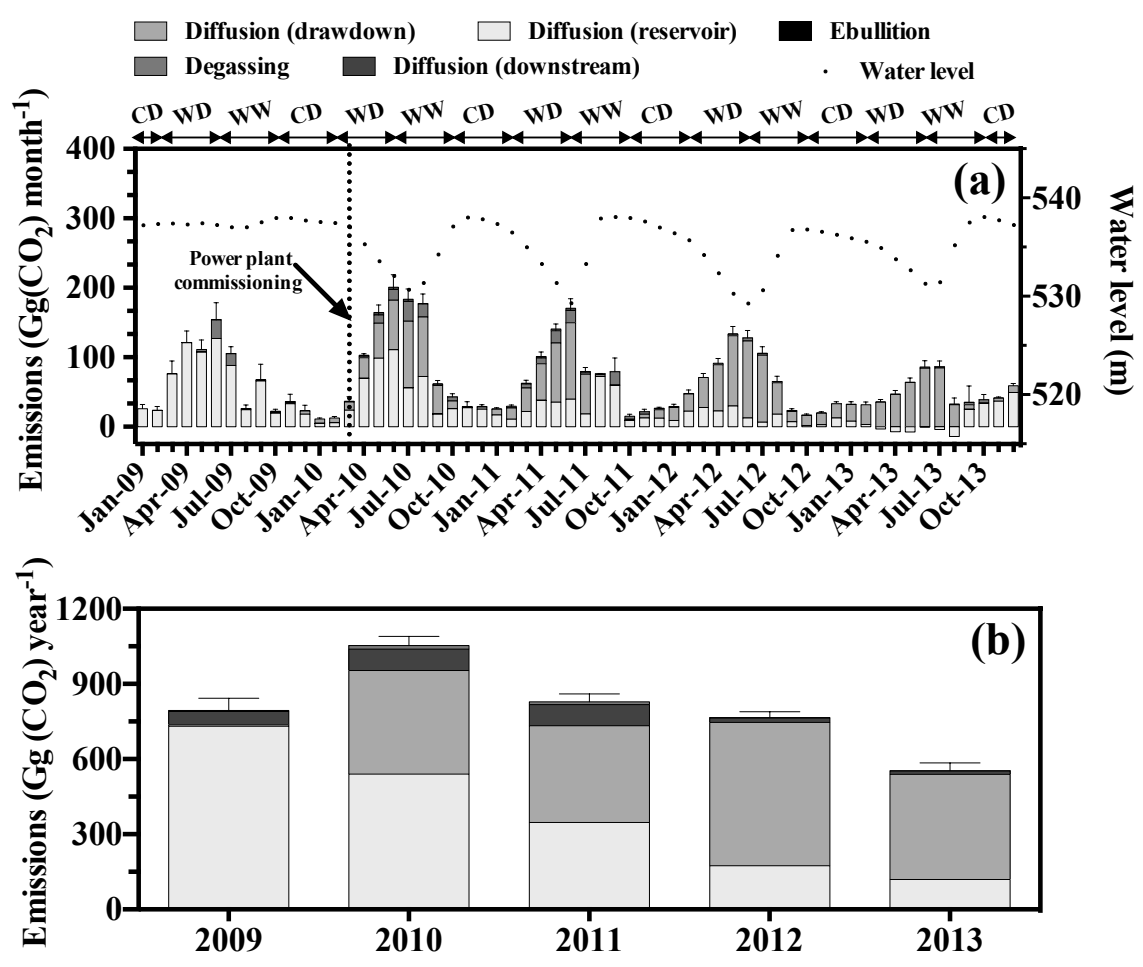

Figure 8. Monthly (a) and yearly (b) average of the total emissions from the Nam Theun 2 Reservoir by diffusion at the reservoir surface, diffusion from the drawdown area, ebullition, degassing and diffusion from the Nam Theun River and artificial channel at the Nam Theun 2 Reservoir (Lao PDR). In panel (a), water-level variations in the reservoir are also given.

the watershed. Downstream of the powerhouse, $\mathrm{CO}_{2}$ concentrations in 2010 were in the same order of magnitude as in 10-20 year-old reservoirs in South America flooding tropical forest (Abril et al., 2005; Guérin et al., 2006; Kemenes et al., 2011), whereas 4 years after impoundment $\mathrm{CO}_{2}$ concentrations were 2 times lower than in 20-30 year-old reservoirs in Lao PDR (Chanudet et al., 2011). We hypothesize that the low $\mathrm{CO}_{2}$ concentration downstream of the NT2R result from a significant degassing of the water at the water intake before the water is transferred downstream as observed for $\mathrm{CH}_{4}$ (Deshmukh et al., 2016; Guérin et al., 2016).

\subsection{Total $\mathrm{CO}_{2}$ emissions from the Nam Theun 2 Reservoir}

From 2009 to 2013, total $\mathrm{CO}_{2}$ emissions from NT2R show the same seasonal pattern (Fig. 8a). The lowest total emissions occur in the $\mathrm{CD}$ season while the highest emissions occur at the transition between the WD and WW seasons, when emissions by all individual pathways reach their maximum. From 2010 to 2013, emissions at the transition between the WD and WW seasons (April-July) contributed 47 to $61 \%$ of total annual emissions suggesting that quantification of emissions based on two to four campaigns in a year might be subject to caution since seasonality of emissions significantly affects emission factors.

$\mathrm{CO}_{2}$ bubbling follows the same seasonal variations, being triggered by water level and concomitant hydrostatic decrease as for $\mathrm{CH}_{4}$ (Chanton et al., 1989; Engle and Melack, 2000; Smith et al., 2000; Boles et al., 2001; Deshmukh et al., 2014), but its contribution is negligible $(<1 \%$, Table 3$)$. Low $\mathrm{CO}_{2}$ emission by bubbling, as also observed in temperate reservoirs (Bevelhimer et al., 2016), is attributed to the higher solubility of $\mathrm{CO}_{2}$ in water than $\mathrm{CH}_{4}$ which leads to the solubilization of the majority of $\mathrm{CO}_{2}$ as free $\mathrm{CO}_{2}$ or as DIC.

The relative contribution of emissions downstream of the reservoir by degassing and diffusion from rivers and channels at NT2R are low as compared to most of the reservoirs that were studied (Abril et al., 2005; Guérin et al., 2006; Kemenes et al., 2011; Bevelhimer et al., 2016), but the contribution of this pathway is comparable to what was observed in boreal reservoirs (Roehm and Tremblay, 2006) or in monomictic reservoirs from Lao PDR (Chanudet et al., 2011). The downstream emissions contributed between $11 \%$ at the maximum in the wet 2011 year down to $3 \%$ at the minimum in 2013 (Table 3 and Fig. 8a). As for $\mathrm{CH}_{4}$ at NT2R (Deshmukh et al., 2016), the low downstream emissions are attributed to the significant degassing at the water intake (station RES9) 
Table 3. $\mathrm{CO}_{2}$ emissions (in $\mathrm{Gg} \mathrm{CO}_{2}$ year $^{-1}$ ) from the Nam Theun 2 Reservoir (Lao PDR) for the first 5 years after impoundment (2009, 2010, 2011, 2012 and 2013). Percentages between brackets represent the proportion of each component to the total annual emission.

\begin{tabular}{|c|c|c|c|c|c|c|}
\hline Year & Ebullition & Diffusion (reservoir) & Diffusion (drawdown) & Degassing & Diffusion (downstream) & Total \\
\hline 2009 & $\begin{array}{r}1.2 \pm 0.5 \\
(<1 \%)\end{array}$ & $\begin{array}{r}730.0 \pm 46.2 \\
(92 \%)\end{array}$ & $\begin{array}{r}6.3 \pm 0.5 \\
(1 \%)\end{array}$ & $\begin{array}{r}52.7 \pm 14.9 \\
(7 \%)\end{array}$ & $\begin{array}{r}4.0 \pm 0.3 \\
(<1 \%)\end{array}$ & $794.1 \pm 48.5$ \\
\hline 2010 & $\begin{array}{r}1.04 \pm 0.5 \\
(<1 \%)\end{array}$ & $\begin{array}{r}538.57 \pm 28.6 \\
(51 \%)\end{array}$ & $\begin{array}{r}413.7 \pm 15.9 \\
(39 \%)\end{array}$ & $\begin{array}{r}85.37 \pm 17.4 \\
(8 \%)\end{array}$ & $\begin{array}{r}14.34 \pm 0.4 \\
(1 \%)\end{array}$ & $1053.0 \pm 37.0$ \\
\hline 2011 & $\begin{array}{r}1.06 \pm 0.5 \\
(<1 \%)\end{array}$ & $\begin{array}{r}345.88 \pm 24.3 \\
(42 \%)\end{array}$ & $\begin{array}{r}386.4 \pm 16.0 \\
(47 \%)\end{array}$ & $\begin{array}{r}84.03 \pm 10.7 \\
(10 \%)\end{array}$ & $\begin{array}{r}11.60 \pm 0.5 \\
(1 \%)\end{array}$ & $828.9 \pm 31.0$ \\
\hline 2012 & $\begin{array}{r}0.95 \pm 0.4 \\
(<1 \%)\end{array}$ & $\begin{array}{r}173.30 \pm 11.5 \\
(23 \%)\end{array}$ & $\begin{array}{r}572.3 \pm 19.9 \\
(75 \%)\end{array}$ & $\begin{array}{r}17.03 \pm 3.8 \\
(2 \%)\end{array}$ & $\begin{array}{r}2.23 \pm 0.2 \\
(<1 \%)\end{array}$ & $765.8 \pm 23.3$ \\
\hline 2013 & $\begin{array}{r}1.04 \pm 0.5 \\
(<1 \%)\end{array}$ & $\begin{array}{r}118.70 \pm 27.3 \\
(21 \%)\end{array}$ & $\begin{array}{r}419 \pm 15.0 \\
(76 \%)\end{array}$ & $\begin{array}{r}13.61 \pm 4.0 \\
(2 \%)\end{array}$ & $\begin{array}{r}1.43 \pm 0.2 \\
(<1 \%)\end{array}$ & $553.8 \pm 31.4$ \\
\hline
\end{tabular}

before the water reach the turbines and to the flush of $\mathrm{CO}_{2}$ due to the reservoir overturn in the $\mathrm{CD}$ season.

Emissions by diffusive fluxes at the surface of the reservoir increased by a factor of 2 by the end of the WD season (Fig. 5a) compared to the CD season from 2009 to 2012. The average $\mathrm{CO}_{2}$ emissions in 2009 and 2010 and to a lesser extend 2011 are in the same range as emissions from the Petit Saut Reservoir during the first 5 years after impoundment (Abril et al., 2005), and in the upper range of average $\mathrm{CO}_{2}$ diffusive fluxes measured in older tropical reservoirs (dos Santos et al., 2006; Kemenes et al., 2011; Yang et al., 2013) or in young boreal reservoirs (Teodoru et al., 2011; Tadonléké et al., 2012). In 2012 and 2013, emissions from NT2R by diffusive fluxes are still higher than most of the older Asian reservoirs (Wang et al., 2011; Chanudet et al., 2011; Xiao et al., 2013; Zhao et al., 2013; Panneer Selvam et al., 2014) and other Brazilian reservoirs flooding savannah (Roland et al., 2010; Pacheco et al., 2015). The low emissions in the CD season from the first 3.5 years might mostly result from lower heterotrophic activity due to the low temperature (down to $7^{\circ} \mathrm{C}$ in air in March 2011). The high emissions in the CD season of 2013 as compared to the CD season in 2011 and 2012 are likely to be originated from additional autochthonous OM. We hypothesize that the significantly higher $\mathrm{CO}_{2}$ emissions in the WD season result from the increase in the water residence time that favour $\mathrm{CO}_{2}$ accumulation in the water column (Abril et al., 2005) and the increase in temperature that enhance aerobic and anaerobic degradation of $\mathrm{OM}$ and the production of $\mathrm{CO}_{2}$ (Sobek et al., 2005). Although the reservoir area during the WD season is the smallest of the year, emissions by diffusive fluxes are the highest (Fig. 8a), highlighting the very significant increase in $\mathrm{CO}_{2}$ emissions from May to July every year, disregarding the year 2013.

This first estimation of the $\mathrm{CO}_{2}$ emission from the drawdown area to the total emission from a reservoir reveals that with a contribution ranging from 40 to more than $75 \%$, it could be a major $\mathrm{CO}_{2}$ pathway to the atmosphere. These results from the NT2R cannot be generalized to all reservoirs since its contribution is tightly linked to the very large water-level variations and large surface area of the drawdown area (up to $320 \mathrm{~km}^{2}$, Fig. 7). However, areal fluxes from the drawdown area are on average 2.5 times higher than the diffusive fluxes from the reservoir water surface in 2009-2010 and 6 times higher than those fluxes in 2013 making the soils in the area of influence of the reservoir a hotspot for $\mathrm{CO}_{2}$ emissions compared to the reservoir surface waters. The total emissions of reservoirs with contrasted hydrology characterized by marked wet and dry seasons and large water-level variations of $30 \%$ of the total surface could have been significantly underestimated as it is the case for Petit Saut $\left(\sim 100 \mathrm{~km}^{2}\right)$, Samuel $\left(\sim 280 \mathrm{~km}^{2}\right)$, Balbina $\left(\sim 220 \mathrm{~km}^{2}\right)$ or The Three Gorges Reservoir $\left(\sim 400 \mathrm{~km}^{2}\right)$ for instance (Guérin et al., 2006; Kemenes et al., 2011; Li et al., 2016). This pathway is expected to be more significant in flatbottom reservoirs than in valley-type reservoirs in mountainous regions and cannot be generalized to just the drawdown area without taking into account hydrological water management and the local topography. At Petit Saut and NT2R at least, no vegetation regrowth occurs in the drawdown areas. Soils at NT2R exhibit very clear modification related to the flooding (stagnic features) confirming soil modification as also observed in Canada (Furey et al., 2004), Australia (Watts, 2000) and France (Feilix-Faure et al., 2017). The ecosystems of the seasonally flooded area are therefore significantly modified and $\mathrm{CO}_{2}$ emissions from the drawdown must be accounted for in total gross emissions from reservoirs. Although drawdown emissions cannot be neglected in terms of gross $\mathrm{CO}_{2}$ exchange, the emissions resulting from the soil respiration are currently comparable to pristine emissions (Table 2) and the impact of these areas in terms of net emissions requires further specific studies in these over- 
looked ecosystems (Prairie et al., 2018). So far, we cannot predict future evolution of $\mathrm{CO}_{2}$ emissions in this area based on the available data. The consequence of the flooding on the respiration rate of these soils may lead to a decrease in emissions with time or a stabilization (see next section). Therefore, the net contribution of the drawdown zone to emissions from the reservoir remains unclear and specifically requires research on soil OM dynamics and would also require the inclusion of the vegetation dynamics when present.

This is the first comprehensive quantification of $\mathrm{CO}_{2}$ emissions from a reservoir where all known $\mathrm{CO}_{2}$ pathways to the atmosphere were taken into account at one of the best spatial and temporal resolutions reported in the literature. We showed that downstream emissions and emissions around the water intake are not negligible $(\sim 10 \%$ overall $)$ and that the overlooked drawdown area in $\mathrm{CO}_{2}$ studies could be the main emission pathway of $\mathrm{CO}_{2}$ to the atmosphere. Overall, this study highlights that global estimate of $\mathrm{CO}_{2}$ emissions from reservoirs are underestimated so far since relevant pathways like drawdown emissions in flat or shallow reservoirs with large water-level variations and downstream emissions in thermally stratified reservoirs are missing in most sitespecific studies used for extrapolations (Deemer et al., 2016; Barros et al., 2011).

\subsection{Source of organic matter fuelling the reservoir $\mathrm{CO}_{2}$ emissions}

In tropical reservoirs, the decrease in the $\mathrm{CO}_{2}$ concentration in the water column and subsequent emissions with the age of the reservoir (Fig. 8b) is supposed to result from the decrease in the aerobic and anaerobic mineralization rate due to the exhaustion of labile OM from the pool of soil and vegetation that was flooded during impoundment (Abril et al., 2005; Guérin et al., 2008). In boreal reservoirs, the decrease in benthic $\mathrm{CO}_{2}$ production is sharp and after 3-5 years, most of the $\mathrm{CO}_{2}$ production appears to be pelagic and is supposed not to result from the flooded OM (Teodoru et al., 2011; Brothers et al., 2012). The total $\mathrm{CO}_{2}$ emissions were 9 and 3 times higher than the carbon inputs from the watershed to the NT2R in 2010 (32 $\mathrm{Gg} \mathrm{C} \mathrm{yr}^{-1}$ ) and 2013 ( $45 \mathrm{Gg} \mathrm{C} \mathrm{yr}^{-1}$ ), respectively (Fig. 3 and Table 3). It has to be noted that interannual variations in carbon inputs to the NT2R (Fig. 3) are not correlated with the regular decrease in total $\mathrm{CO}_{2}$ emissions from year to year (Fig. 8b). It is therefore unlikely that most of $\mathrm{CO}_{2}$ emissions result from the mineralization of allochthonous OM but rather from the contribution of the flooded carbon pool (soil and vegetation), which is decreasing with time. This is consistent with the fact that at Petit Saut, even 10 years after flooding, the majority of the $\mathrm{OM}$ in the water column has a terrestrial origin (De Junet et al., 2009). According to Abril et al. (2005) at Petit Saut, total emissions (disregarding drawdown emissions which were not measured) were 9 to 6 times higher than carbon inputs from the watershed during the first 4 years for similar carbon inputs, which indicates a faster de- crease in emissions in NT2R than at Petit Saut. This sharp decrease in emissions at NT2R might be due to the fact that the flooded pool of OM and therefore the amount of labile OM in NT2R was twice smaller than the amount of OM flooded in the Petit Saut (Guérin et al., 2008; Descloux et al., 2011). We show here, as it was done at Petit Saut (Abril et al., 2005; Guérin et al., 2008), that external sources of carbon are not sufficient to fuel the $\mathrm{CO}_{2}$ emissions from the NT2R and we attribute the decrease in emissions with time to the exhaustion of the most labile fraction of the flooded pool of OM, which might be the main source of reactive carbon in the reservoir.

In the subtropical NT2R, $\mathrm{CO}_{2}$ concentrations are always higher at the bottom than in the epilimnic waters even during the $\mathrm{CD}$ season when the limited thermal stratification or its absence do not favour hypolimnic $\mathrm{CO}_{2}$ accumulation. The $\mathrm{CD}$ season is probably the most favourable season to pelagic respiration as this process is enhanced by the re-oxygenation of the water column (Bastviken et al., 2004). Since $\mathrm{CO}_{2}$ concentration in the $\mathrm{CD}$ season is $50 \%$ lower than in the warm seasons, we suggest that $\mathrm{CO}_{2}$ is mostly produced in the sediment and flooded soils and vegetation. Disregarding the station RES9 located at the water intake, significant spatial variation in $\mathrm{CO}_{2}$ hypolimnic concentrations were found between stations located in the area of dense forest (RES1-3) versus stations located in areas close to the three main tributaries (RES6-8). Stations RES1-3 which have the highest average bottom concentrations are located in areas where the carbon density is $50 \%$ higher than the agricultural ecosystems that were flooded in the area of the stations RES6-8 (Descloux et al., 2011).

In the absence of significant vegetation regrowth in the drawdown area during the study period, the main source of carbon fuelling emissions from the drawdown area are not clearly identified. Immediately after flooding, the most labile part of the soil $\mathrm{OM}$ and the decomposing vegetation must have been the main sources of $\mathrm{C}$ fuelling the emissions. In the long run, the atmospheric carbon sink associated with the pristine vegetation dynamics has been lost, but as a consequence the loss of this vegetation might reduce labile OM inputs. In addition, the water-level variations erode the soil and OM is transferred to the reservoir and ultimately to the sediments or downstream (Feilix-Faure et al., 2017). Those carbon losses should have resulted in or should result in the future in a decrease in $\mathrm{CO}_{2}$ emissions from the drawdown. The stability of emissions throughout our 4-year surveys in the drawdown area suggests that a new carbon source might have contributed to emissions. Development of micro-phytobenthos or microbial biofilms as often observed in estuaries on mudflats (de Brouwer and Stal, 2001) or along streams in logged riparian areas (Sabater et al., 2000) could supply labile OM to the system and favour a priming effect (Guenet et al., 2010). Through this effect, the inputs of labile OM stimulate the degradation/mineralization of recalcitrant/stabilized OM. This effect might be enhanced by the 
oxic/anoxic oscillation that would favour the mineralization of different pools of OM than those that would have been otherwise degraded in stable conditions (Abril et al., 1999; Bastviken et al., 2004). Overall, we hypothesized that the oxic/anoxic variations and priming effect through the development of algae and bacteria might have contributed to the stability of $\mathrm{CO}_{2}$ emissions from these soils under the influence of the reservoir. So far we found no clear evidence of a significant carbon loss in the soils of the drawdown area by comparing surface soil organic matter from pristine upland soils and from the shoreline (Table 1). A comprehensive study of carbon density down to the bedrock would be necessary since we found very clear evidence of inundation patterns down to $1 \mathrm{~m}$ (P. Oliva, unpublished). In addition to the full carbon stock, detailed OM characterization might be needed for the identification of changes in the pool of soil OM.

The overall confirmation of the importance of the flooded pool of OM in the carbon cycling in a tropical reservoir highlights the differences in functioning with boreal reservoirs where the degradation of the flooded OM within a few years does not contribute significantly to emissions (Brothers et al., 2012). In addition to a strong temperature effect on mineralization of OM (Gudasz et al., 2010), the probable low lability and good capacity for preservation of peat-dominated OM might explain the different origin of OM fuelling emissions between these two distinct climatic areas.

\section{Conclusions}

We presented the first comprehensive estimation of $\mathrm{CO}_{2}$ emissions from a subtropical reservoir starting less than a year after reservoir impoundment and lasting 4.5 years. This estimation includes all known pathways to the atmosphere: emissions from the reservoir surface, downstream emissions and emissions from the drawdown area.

More than $50 \%$ of total emissions occur within 3-4 months during the warmest period of the year at the transition between the dry and the wet seasons. Such a result suggests that quantification of emissions based on two to four campaigns in a year might significantly positively or negatively affect emission factors and carbon budgets of ecosystems under study.

The smooth decrease in total emissions over the years coupled with the fact that the incoming flux of carbon from the watershed to the reservoir represents less than a third of the total emissions, are a strong indication that the flooded pool of $\mathrm{OM}$ is the main source of carbon fuelling emissions. The carbon density of flooded soil and biomass in reservoirs appears to be a key controlling factor of emissions and should be included for future estimation of greenhouse gas emissions from reservoirs.

We found that gross $\mathrm{CO}_{2}$ emissions from the drawdown area represented $40-75 \%$ of the total emissions from the
NT2R and they occur within a few months during low waterlevel seasons. The soil OM from these areas undergoes anaerobic degradation and fuels the reservoir water column with $\mathrm{CO}_{2}$ during the wet season. In the dry season, the soil loses $\mathrm{CO}_{2}$ directly to the atmosphere while undergoing both aerobic and anaerobic mineralization depending on the soil moisture content. We hypothesize that both (1) the potential development of bacteria and micro-phytobenthos at the surface of these soils and (2) the oxic/anoxic variations contribute to the mineralization of stabilized soil organic matter leading to a sustained high soil respiration even after the pristine vegetation decayed. This overlooked pathway in terms of gross emissions would require an in-depth evaluation for the soil $\mathrm{OM}$, vegetation dynamics and long-term monitoring of emissions to evaluate the real contribution of this area in terms of net modification of gas exchange in the footprint of the reservoir.

Data availability. Datasets are property of EDF, NTPC and Paul Sabatier University and are not public, but could be available on request (frederic.guerin@ird.fr).

Competing interests. The authors declare that they have no conflict of interest.

Special issue statement. This article is part of the special issue "Human impacts on carbon fluxes in Asian river systems". It is not associated with a conference.

Acknowledgements. The authors thank everyone who contributed to the NT2 monitoring programme, especially the Nam Theun 2 Power Company (NTPC), Electricité de France (EDF) and CNRS-INSU (Submersoil project, EC2CO-BIOHEFECT) for providing financial, technical and logistic support. We are also grateful to the Aquatic Environment Laboratory of the Nam Theun 2 Power Company whose shareholders are EDF, Lao Holding State Enterprise and Electricity Generating Public Company Limited of Thailand. Chandrashekhar Deshmukh benefited from a PhD grant by EDF.

Edited by: Vedula V. S. S. Sarma

Reviewed by: Nittala Sarma and one anonymous referee

\section{References}

Abril, G., Etcheber, H., Le Hir, P., Bassoullet, P., Boutier, B., and Frankignoulle, M.: Oxic/anoxic oscillations and organic carbon mineralization in an estuarine maximum turbidity zone (The Gironde, France), Limnol. Oceanogr., 44, 1304-1315, 1999.

Abril, G., Guérin, F., Richard, S., Delmas, R., Galy-Lacaux, C., Gosse, P., Tremblay, A., Varfalvy, L., Dos Santos, M. A., and Matvienko, B.: Carbon dioxide and methane emissions and 
the carbon budget of a 10-year old tropical reservoir (Petit Saut, French Guiana), Global Biogeochem. Cy., 19, Gb4007, https://doi.org/10.1029/2005gb002457, 2005.

Abril, G., Commarieu, M.-V., and Guérin, F.: Enhanced methane oxidation in an estuarine turbidity maximum, Limnol. Oceanogr., 52, 470-475, 2007.

Barros, N., Cole, J. J., Tranvik, L. J., Prairie, Y. T., Bastviken, D., Huszar, V. L. M., del Giorgio, P., and Roland, F.: Carbon emission from hydroelectric reservoirs linked to reservoir age and latitude, Nat. Geosci., 4, 593-596, 2011.

Bastviken, D., Persson, L., Odham, G., and Tranvik, L.: Degradation of dissolved organic matter in oxic and anoxic lake water, Limnol. Oceanogr., 49, 109-116, 2004.

Bevelhimer, M., Stewart, A., Fortner, A., Phillips, J., and Mosher, J.: $\mathrm{CO}_{2}$ is Dominant Greenhouse Gas Emitted from Six Hydropower Reservoirs in Southeastern United States during Peak Summer Emissions, Water, 8, 1-14, 2016.

Boles, J. R., Clark, J. F., Leifer, I., and Washburn, L.: Temporal variation in natural methane seep rate due to tides, Coal Oil Point area, California, J. Geophys. Res.-Oceans, 106, 27077-27086, https://doi.org/10.1029/2000JC000774, 2001.

Brothers, S. M., Prairie, Y. T., and del Giorgio, P. A.: Benthic and pelagic sources of carbon dioxide in boreal lakes and a young reservoir (Eastmain-1) in eastern Canada, Global Biogeochem. Cy., 26, GB1002, https://doi.org/10.1029/2011gb004074, 2012.

Chanton, J. P., Martens, C. S., and Kelley, C. A.: Gas Transport from Methane-Saturated, Tidal Freshwater and Wetland Sediments, Limnol. Oceanogr., 34, 807-819, 1989.

Chanudet, V., Descloux, S., Harby, A., Sundt, H., Hansen, B. H., Brakstad, O., Serca, D., and Guérin, F.: Gross $\mathrm{CO}_{2}$ and $\mathrm{CH}_{4}$ emissions from the Nam Ngum and Nam Leuk sub-tropical reservoirs in Lao PDR, Sci. Total Environ., 409, 5382-5391, https://doi.org/10.1016/j.scitotenv.2011.09.018, 2011.

Chanudet, V., Fabre, V., and van der Kaaij, T.: Application of a three-dimensional hydrodynamic model to the Nam Theun 2 Reservoir (Lao PDR), J. Great Lakes Res., 38, 260-269, https://doi.org/10.1016/j.jglr.2012.01.008, 2012.

Chen, H., Wu, Y., Yuan, X., Gao, Y., Wu, N., and Zhu, D.: Methane emissions from newly created marshes in the drawdown area of the Three Gorges Reservoir, J. Geophys. Res., 114, D18301, https://doi.org/10.1029/2009JD012410, 2009.

Chen, H., Yuan, X., Chen, Z., Wu, Y., Liu, X., Zhu, D., Wu, N., Zhu, Q. a., Peng, C., and Li, W.: Methane emissions from the surface of the Three Gorges Reservoir, J. Geophys. Res., 116, D21306, https://doi.org/10.1029/2011jd016244, 2011.

de Brouwer, J. F. C. and Stal, L. J.: Short-term dynamics in microphytobenthos distribution and associated extracellular carbohydrates in surface sediments of an intertidal mudflat, Mar. Ecol. Prog. Ser., 218, 33-44, 2001.

Deemer, B. R., Harrison, J. A., Li, S., Beaulieu, J. J., DelSontro, T., Barros, N., Bezerra-Neto, J. F., Powers, S. M., dos Santos, M. A., and Vonk, J. A.: Greenhouse Gas Emissions from Reservoir Water Surfaces: A New Global Synthesis, BioScience, 66, 949964, https://doi.org/10.1093/biosci/biw117, 2016.

De Junet, A., Abril, G., Guérin, F., Billy, I., and De Wit, R.: A multitracers analysis of sources and transfers of particulate organic matter in a tropical reservoir (Petit Saut, French Guiana), River Res. Appl., 25, 253-271, https://doi.org/10.1002/rra.1152, 2009.
Demarty, M., Bastien, J., and Tremblay, A.: Annual follow-up of gross diffusive carbon dioxide and methane emissions from a boreal reservoir and two nearby lakes in Québec, Canada, Biogeosciences, 8, 41-53, https://doi.org/10.5194/bg-8-41-2011, 2011.

Descloux, S., Chanudet, V., Poilvé, H., and Grégoire, A.: Coassessment of biomass and soil organic carbon stocks in a future reservoir area located in Southeast Asia, Environ. Monit. Assess., 173, 723-741, https://doi.org/10.1007/s10661-010-1418-3, 2011.

Descloux, S., Guedant, P., Phommachanh, D., and Luthi, R.: Main features of the Nam Theun 2 hydroelectric project (Lao PDR) and the associated environmental monitoring programmes, Hydroécol. Appl., 19, 5-25, 2016.

Deshmukh, C., Serça, D., Delon, C., Tardif, R., Demarty, M., Jarnot, C., Meyerfeld, Y., Chanudet, V., Guédant, P., Rode, W., Descloux, S., and Guérin, F.: Physical controls on $\mathrm{CH}_{4}$ emissions from a newly flooded subtropical freshwater hydroelectric reservoir: Nam Theun 2, Biogeosciences, 11, 4251-4269, https://doi.org/10.5194/bg-11-4251-2014, 2014.

Deshmukh, C., Guérin, F., Labat, D., Pighini, S., Vongkhamsao, A., Guédant, P., Rode, W., Godon, A., Chanudet, V., Descloux, S., and Serça, D.: Low methane $\left(\mathrm{CH}_{4}\right)$ emissions downstream of a monomictic subtropical hydroelectric reservoir (Nam Theun 2, Lao PDR), Biogeosciences, 13, 1919-1932, https://doi.org/10.5194/bg-13-1919-2016, 2016.

dos Santos, M. A., Rosa, L. P., Sikar, B., Sikar, E., and dos Santos, E. O.: Gross greenhouse gas fluxes from hydro-power reservoir compared to thermo-power plants, Energ. Policy, 34, 481-488, https://doi.org/10.1016/j.enpol.2004.06.015, 2006.

Engle, D. and Melack, J. M.: Methane emissions from an Amazon floodplain lake: Enhanced release during episodic mixing and during falling water, Biogeochemistry, 51, 71-90, 2000.

Feìlix-Faure, J., Chanudet, V., Walter, C., Dorioz, J.-M., Baudoin, J.-M., Lissolo, T., Descloux, S., and Dambrine, E.: Evolution des sols ennoyés sous les retenues de barrage: Influence sur l'écologie des plans d'eau et la dynamique des gaz à effet de serre, Etude et Gestion des Sols, 24, 45-58, 2017.

Furey, P. C., Nordin, R. N., and Mazumder, A.: Water Level Drawdown Affects Physical and Biogeochemical Properties of Littoral Sediments of a Reservoir and a Natural Lake, Lake Reserv. Manage., 20, 280-295, https://doi.org/10.1080/07438140409354158, 2004.

Galy-Lacaux, C., Delmas, R., Dumestre, J.-F., and Richard, S.: Evolution temporelle des émissions gazeuses et des profils de gaz dissous Estimation du bilan de carbone de la retenue de PetitSaut deux ans après sa mise en eau, Hydroécol. Appl., 9, 85-114, 1997a.

Galy-Lacaux, C., Delmas, R., Jambert, C., Dumestre, J. F., Labroue, L., Richard, S., and Gosse, P.: Gaseous emissions and oxygen consumption in hydroelectric dams: A case study in French Guyana, Global Biogeochem. Cy., 11, 471-483, $1997 \mathrm{~b}$.

Gudasz, C., Bastviken, D., Steger, K., Premke, K., Sobek, S., and Tranvik, L. J.: Temperature-controlled organic carbon mineralization in lake sediments, Nature, 466, 478-481, 2010.

Guenet, B., Danger, M., Abbadie, L., and Lacroix, G.: Priming effect: bridging the gap between terrestrial and aquatic ecology, Ecology, 91, 2850-2861, https://doi.org/10.1890/09-1968.1, 2010 . 
Guérin, F. and Abril, G.: Significance of pelagic aerobic methane oxidation in the methane and carbon budget of a tropical reservoir, J. Geophys. Res.-Biogeo., 112, G03006, https://doi.org/10.1029/2006JG000393, 2007.

Guérin, F., Abril, G., Richard, S., Burban, B., Reynouard, C., Seyler, P., and Delmas, R.: Methane and carbon dioxide emissions from tropical reservoirs: Significance of downstream rivers, Geophys. Res. Lett., 33, L21407, https://doi.org/10.1029/2006g1027929, 2006.

Guérin, F., Abril, G., Serça, D., Delon, C., Richard, S., Delmas, R., Tremblay, A., and Varfalvy, L.: Gas transfer velocities of $\mathrm{CO}_{2}$ and $\mathrm{CH}_{4}$ in a tropical reservoir and its river downstream, J. Mar. Syst., 66, 161-172, 2007.

Guérin, F., Abril, G., de Junet, A., and Bonnet, M.-P.: Anaerobic decomposition of tropical soils and plant material: Implication for the $\mathrm{CO}_{2}$ and $\mathrm{CH}_{4}$ budget of the Petit Saut Reservoir, Appl. Geochem., 23, 2272-2283, https://doi.org/10.1016/j.apgeochem.2008.04.001, 2008.

Guérin, F., Deshmukh, C., Labat, D., Pighini, S., Vongkhamsao, A., Guédant, P., Rode, W., Godon, A., Chanudet, V., Descloux, S., and Serça, D.: Effect of sporadic destratification, seasonal overturn, and artificial mixing on $\mathrm{CH}_{4}$ emissions from a subtropical hydroelectric reservoir, Biogeosciences, 13, 3647-3663, https://doi.org/10.5194/bg-13-3647-2016, 2016.

Kemenes, A., Forsberg, B. R., and Melack, J. M.: $\mathrm{CO}_{2}$ emissions from a tropical hydroelectric reservoir (Balbina, Brazil), J. Geophys. Res., 116, G03004, https://doi.org/10.1029/2010jg001465, 2011.

Li, Z., Zhang, Z., Lin, C., Chen, Y., Wen, A., and Fang, F.: Soil-air greenhouse gas fluxes influenced by farming practices in reservoir drawdown area: A case at the Three Gorges Reservoir in China, J. Environ. Manage., 181, 64-73, https://doi.org/10.1016/j.jenvman.2016.05.080, 2016.

Lovatt Smith, P. F., Stokes, R. B., Bristow, C., and Carter, A.: Mid-Cretaceous inversion in the Northern Khorat Plateau of Lao PDR and Thailand, Geol. Soc. SP, 106, 233-247, https://doi.org/10.1144/gsl.sp.1996.106.01.15, 1996.

MacIntyre, S., Jonsson, A., Jansson, M., Aberg, J., Turney, D. E., and Miller, S. D.: Buoyancy flux, turbulence, and the gas transfer coefficient in a stratified lake, Geophys. Res. Lett., 37, L24604, https://doi.org/10.1029/2010GL044164, 2010.

Marotta, H., Pinho, L., Gudasz, C., Bastviken, D., Tranvik, L. J., and Enrich-Prast, A.: Greenhouse gas production in low-latitude lake sediments responds strongly to warming, Nat. Clim. Change, 4, 467-470, https://doi.org/10.1038/nclimate2222, 2014.

Pacheco, F. S., Soares, M. C. S., Assireu, A. T., Curtarelli, M. P., Roland, F., Abril, G., Stech, J. L., Alvalá, P. C., and Ometto, J. P.: The effects of river inflow and retention time on the spatial heterogeneity of chlorophyll and water-air $\mathrm{CO}_{2}$ fluxes in a tropical hydropower reservoir, Biogeosciences, 12, 147-162, https://doi.org/10.5194/bg-12-147-2015, 2015.

Panneer Selvam, B., Natchimuthu, S., Arunachalam, L., and Bastviken, D.: Methane and carbon dioxide emissions from inland waters in India - implications for large scale greenhouse gas balances, Glob. Change Biol., 20, 3397-3407, https://doi.org/10.1111/gcb.12575, 2014.

Prairie, Y. T., Alm, J., Beaulieu, J., Barros, N., Battin, T., Cole, J., del Giorgio, P., DelSontro, T., Guérin, F., Harby, A., Harrison, J., Mercier-Blais, S., Serça, D., Sobek, S., and Vachon, D.: Greenhouse Gas Emissions from Freshwater Reservoirs: What Does the Atmosphere See?, Ecosystems, https://doi.org/10.1007/s10021-017-0198-9, in press, 2018.

Raymond, P. A., Hartmann, J., Lauerwald, R., Sobek, S., McDonald, C., Hoover, M., Butman, D., Striegl, R., Mayorga, E., Humborg, C., Kortelainen, P., Durr, H., Meybeck, M., Ciais, P., and Guth, P.: Global carbon dioxide emissions from inland waters, Nature, 503, 355-359, 2013.

Roehm, C. and Tremblay, A.: Role of turbines in the carbon dioxide emissions from two boreal reservoirs, Quebec, Canada, J. Geophys. Res.-Atmos., 111, D24101, https://doi.org/10.1029/2006jd007292, 2006.

Roland, F., Vidal, L. O., Pacheco, F. S., Barros, N. O., Assireu, A., Ometto, J., Cimbleris, A. C. P., and Cole, J. J.: Variability of carbon dioxide flux from tropical (Cerrado) hydroelectric reservoirs, Aquat. Sci., 72, 283-293, https://doi.org/10.1007/s00027010-0140-0, 2010.

Sabater, F., Butturini, A., Martí, E., Muñoz, I., Romaní, A., Wray, J., and Sabater, S.: Effects of riparian vegetation removal on nutrient retention in a Mediterranean stream, J. N. Am. Benthol. Soc., 19, 609-620, https://doi.org/10.2307/1468120, 2000.

Serça, D., Delmas, R., Jambert, C., and Labroue, L.: Emissions of nitrogen oxides from equatorial rain forest in central Africa, Tellus B, 46, 243-254, https://doi.org/10.3402/tellusb.v46i4.15795, 1994.

Serça, D., Deshmukh, C., Pighini, S., Oudone, P., Vongkhamsao, A., Guédant, P., Rode, W., Godon, A., Chanudet, V., Descloux, S., and Guérin, F.: Nam Theun 2 Reservoir four years after commissioning: significance of drawdown methane emissions and other pathways, Hydroécol. Appl., 19, 119-146, 2016.

Smith, L. K., Lewis, W. M., Chanton, J. P., Cronin, G., and Hamilton, S. K.: Methane emissions from the Orinoco River floodplain, Venezuela, Biogeochemistry, 51, 113-140, https://doi.org/10.1023/a:1006443429909, 2000.

Smith, P. F. L. and Stokes, R. B.: Geology and petroleum potential of the Khorat Plateau basin in the Vientiane area of LAO P.D.R, J. Petrol. Geol., 20, 27-49, https://doi.org/10.1111/j.17475457.1997.tb00754.x, 1997.

Sobek, S., Tranvik, L. J., and Cole, J. J.: Temperature independence of carbon dioxide supersaturation in global lakes, Glob. Biogeochem. Cy., 19, GB2003, https://doi.org/10.1029/2004gb002264, 2005.

St Louis, V. L., Kelly, C. A., Duchemin, E., Rudd, J. W. M., and Rosenberg, D. M.: Reservoir surfaces as sources of greenhouse gases to the atmosphere: A global estimate, Bioscience, 50, 766$775,2000$.

Tadonléké, R. D., Marty, J., and Planas, D.: Assessing factors underlying variation of $\mathrm{CO}_{2}$ emissions in boreal lakes vs. reservoirs, FEMS Microbiol. Ecol., 79, 282-297, https://doi.org/10.1111/j.1574-6941.2011.01218.x, 2012.

Teodoru, C. R., Prairie, Y. T., and del Giorgio, P. A.: Spatial Heterogeneity of Surface $\mathrm{CO}_{2}$ Fluxes in a Newly Created Eastmain-1 Reservoir in Northern Quebec, Canada, Ecosystems, 14, 28-46, https://doi.org/10.1007/s10021-010-9393-7, 2011.

Teodoru, C. R., Bastien, J., Bonneville, M.-C., del Giorgio, P. A., Demarty, M., Garneau, M., Hélie, J.-F., Pelletier, L., Prairie, Y. T., Roulet, N. T., Strachan, I. B., and Tremblay, A.: The net carbon footprint of a newly created boreal hy- 
droelectric reservoir, Global Biogeochem. Cy., 26, GB2016, https://doi.org/10.1029/2011gb004187, 2012.

Wang, F., Wang, B., Liu, C.-Q., Wang, Y., Guan, J., Liu, $\mathrm{X}$, and $\mathrm{Yu}, \mathrm{Y} .:$ Carbon dioxide emission from surface water in cascade reservoirs-river system on the Maotiao River, southwest of China, Atmos. Environ., 45, 3827-3834, https://doi.org/10.1016/j.atmosenv.2011.04.014, 2011.

Watts, C. J.: Seasonal phosphorus release from exposed, reinundated littoral sediments of two Australian reservoirs, Hydrobiologia, 431, 27-39, https://doi.org/10.1023/a:1004098120517, 2000.

Weiss, R. F.: Carbon dioxide in water and seawater: the solubility of a non-ideal gas, Mar. Chem., 2, 203-215, https://doi.org/10.1016/0304-4203(74)90015-2, 1974.

Xiao, S., Wang, Y., Liu, D., Yang, Z., Lei, D., and Zhang, C.: Diel and seasonal variation of methane and carbon dioxide fluxes at Site Guojiaba, the Three Gorges Reservoir, J. Environ. Sci., 25, 2065-2071, https://doi.org/10.1016/S1001-0742(12)60269$1,2013$.

Yang, L., Lu, F., Wang, X., Duan, X., Song, W., Sun, B., Chen, S., Zhang, Q., Hou, P., Zheng, F., Zhang, Y., Zhou, X., Zhou, Y., and Ouyang, Z.: Surface methane emissions from different land use types during various water levels in three major drawdown areas of the Three Gorges Reservoir, J. Geophys. Res.-Atmos., 117, D10109, https://doi.org/10.1029/2011JD017362, 2012.
Yang, L., Lu, F., Wang, X., Duan, X., Tong, L., Ouyang, Z., and $\mathrm{Li}, \mathrm{H}$.: Spatial and seasonal variability of $\mathrm{CO}_{2}$ flux at the airwater interface of the Three Gorges Reservoir, J. Environ. Sci., 25, 2229-2238, https://doi.org/10.1016/S1001-0742(12)602915, 2013.

Yvon-Durocher, G., Allen, A. P., Bastviken, D., Conrad, R., Gudasz, C., St-Pierre, A., Thanh-Duc, N., and del Giorgio, P. A.: Methane fluxes show consistent temperature dependence across microbial to ecosystem scales, Nature, 507, 488-491, https://doi.org/10.1038/nature13164, 2014.

Zhao, Y., Wu, B. F., and Zeng, Y.: Spatial and temporal patterns of greenhouse gas emissions from Three Gorges Reservoir of China, Biogeosciences, 10, 1219-1230, https://doi.org/10.5194/bg-10-1219-2013, 2013. 